\title{
BELGELERIN GÖZÜNDEN HASAN TAHSIN VE "İLK KURŞUN" MESELESINE YENIDEN BAKMAK
}

\author{
MITHAT KADRİ VURAL*
}

\begin{abstract}
Öz
Hasan Tahsin'in “ilk kurşunu” atarak Millî Mücadeleyi başlattığ1 tezi tarih anlatımına sonradan eklemlenmiştir. Başta Nutuk olmak üzere Millî Mücadele tarihini anlatan birincil el kaynaklarda "Hasan Tahsin" ve "ilk kurşun” anlatısı yer almaz. Bu çalışma Hasan Tahsin'in “ilk kurşunu” atarak Millî Mücadeleyi başlattığı tezine eleştirel bir yaklaşımla yeniden bakmayı amaçlamaktadır. Tarih biliminin araştırma yöntemlerine uygun olarak öncelikle birinci el kaynaklar taranmıştır. Nitekim Osmanlı arşivinde zengin bir belge içeriği ile karşılaşılmıştır. Ardından konuyla ilgili yabancı arşiv belgelerine başvurulmuş ve son olarak da dönemin Türk basınında yer alan haberler değerlendirmeye alınmıştır. Görgü tanıklarının aktardıkları ise geniş bir literatürü kapsadığı için ayrı makale konusu olarak düşünülmüş ve söz konusu çalışmanın d1şında bırakılmıştır.
\end{abstract}

Anahtar Kelimler: Hasan Tahsin, İlk Kurşun, İzmir, Osman Nevres.

Dr., Dokuz Eylül Ünversitesi Atatürk İlkeleri ve İnkılap Tarihi Enstitüsü, mithat.vural@deu.edu.tr ORCID: 0000-0002-3900-7109 DOI: 10.33419/aamd.642346

Makale Gönderim Tarihi: 05.02.2019 Makale Kabul Tarihi: 09.10.2019 


\title{
A NEW PERSPECTIVE TO THE ISSUE OF HASAN TAHSIN AND "THE FIRST BULLET" THROUGH DOCUMENTS
}

\begin{abstract}
The thesis that Hasan Tahsin initiated the national struggle by being the first to open fire was later added to historical narrative. The narrative about "Hasan Tahsin" and "the first bullet" can't be found in the primary sources about the history of national struggle, notably in Nutuk. With a critical approach, this study aims to re-examine the thesis that Hasan Tahsin initiated the national struggle by being the first to open fire. In accordance with the historical methods, primary sources were first reviewed. As a matter of fact, a large number of documents were found in the Ottoman archives.Then, foreign archive documents related to the subject were revised, and finally the news in the Turkish press at that time were also investigated. Since eyewitness reports cover an extensive literature, it was considered a separate article subject and was left out of the study.
\end{abstract}

Keywords: Hasan Tahsin, The first bullet, Izmir, Osman Nevres. 


\section{GíRIŞ}

Birinci Dünya Savaşı'ndan sonra 18 Ocak 1919'da başlayan Paris Barış Konferansı'nda Yunanistan Başbakanı Eleftheros Venizelos, yenilmiş Osmanlı Devleti'nden bir "Yunan İmparatorluğu" çıkarma peşindeydi. Bu konuda en başından beri kendisini "Perikles zamanından beri Yunanistan'dan çıkan en büyük devlet adamı" olarak niteleyen İngiltere Başbakanı Lloyd George'u ikna etmeyi başarmıştı. Venizelos'un Paris'teki performansından oldukça etkilenen İngiliz diplomat Harold Nicolson babasına yazdığı mektupta bu durumu "Lenin ve O, Avrupa'daki gerçek iki büyük adam" sözleriyle aktaracaktır'. Venizelos ilk olarak 4 Şubat 1919'da Barış Konseyi'ne, Wilson ilkeleri çerçevesinde bölgede yaşayan Rumların çoğunlukta olduğunu öne sürerek İzmir'in, Yunanistan'a bırakılması gerektiğini savundu. Hatta bölgenin bir an önce Yunan egemenliğine bırakılmaması halinde Batı Anadolu'da bulunan Rumların katliam tehdidiyle karşı karşıya olduğunu öne sürdü. Bunun üzerine 12 Şubat'ta İngiltere ve Fransa'nın önerisiyle Yunan tezlerinin araştırılması konusunda bir komisyon kurulması kararlaştırıldı. Bu süreçte Venizelos, Yunanistan İçişleri Bakanına gönderdiği telgrafta, İzmir'de bulunan örgüt liderleriyle bağlantıya geçmesi ve yerli Rumları "Enosis konusunda ne kadar istekli olduklarını ortaya koymaları konusunda" cesaretlendirmesi talimatını verdi ${ }^{2}$. Ayrıca bunun hiç bir şekilde hükûmetten gelen bir emir doğrultusunda gerçekleştirildiği izlenimi verilmemeliydi. Nitekim İzmir'de bütün çabaların merkezinde Metropolit Hrisostomos yer alacaktı.

\section{I. İzmir'in Yunan Ordusu Tarafından İşgali}

İzmir ve Batı Anadolu kıyılarının gizli anlaşmalarla İtalya'ya tanınmış s1nırlar içinde olması, İtalya ile Yunanistan'ı karşı karşıya getirdi. Yunanistan'ın hamlesine karşılık İtalyan Hükümeti ise bölgedeki Türklerle yapılacak işbirliği neticesinde İzmir'in Yunanistan'a bırakılması ihtimalinin ortadan kalkabileceğini düşünmekte ve bu konuda harekete geçmek için politikalar geliştirmeye çalışmaktaydı. Bu arada İtalya'nın Batı Anadolu kıyılarına yönelik işgal politikası ve İzmir' in İtalyan kuvvetleri tarafindan işgal olasılığının yarattığ tedirginlik, büyük devletleri İzmir ile ilgili Yunanistan lehine karar almaya

1 Giles Milton, Kayıp Cennet Smyrna 1922 Hoşgörü Kentinin Yıkılışı, Şenocak Yayınlar1, İzmir, 2009, s. 39.

2 Gürhan Yellice, "Megali İdea M1 Mare Nostrum Mu? Mondros Mütarekesi'nden İzmir'in İşgaline İtalyan-Yunan İlişkileri ve Propaganda Savaşı, 1918-1919”, Tarih Okulu Dergisi, S XXXVI, Ekim 2018, s. 181. 
itecekti. Fethiye, Kuşadası ve Marmaris'e yapılan İtalyan çıkartması dışında İzmir Körfezi'ne İtalyan gemilerinin gönderilmesi Nicolson'un ifadesiyle "Yunanlılara fark etmeden büyük bir yardım" anlamına gelmekteydi3. Nitekim 24 Nisan'da İtilaf Devletlerinin İtalyanlara Adriyatik'te bir liman olan Fiume'yi vermeyi reddetmelerinden dolayı İtalya Başbakanı Vittorio Emanuele Orlando'nun konferansı terk etmesi İzmir ile ilgili karar sürecini hızlandiracaktı.

İtalya'nın muhalefetine rağmen Mayıs ayı başında ABD, İngiltere ve Fransa liderleri arasında yapılan görüşmelerin ardından Yunanistan donanmasının İzmir'e çıkarma yapması konusunda uzlaşmaya varıldı. Bu doğrultuda 14 Mayıs günü İstanbul'daki İngiliz Yüksek Komiser Vekili Amiral Richard Webb, Sadrazam Damat Ferit Paşa'ya İzmir tabyalarının işgal edileceğine yönelik bir nota verdi. Aynı gün içinde İzmir'de, İngiltere'nin Yüksek Komiseri olarak görev yapan Amiral Somerset Arthur Gough Calthorpe ise Vali İzzet Bey ile 17. Kolordu Komutanı Ali Nadir Paşa'ya aynı notayı, İngiltere'nin İzmir Konsolosu James Morgan ile İngiliz Yarbay Ian Smith aracıllğıyla iletti. Vali İzzet Bey notayı aldıktan sonra Iron Duke zırhlısına giderek Calthorpe ile görüşür. 14 Mayıs akşamı ise Amiral Calthorpe'nin İzmir'in Yunanlılar tarafından işgal edileceğini bildiren notası James Morgan tarafından Vali İzzet Bey'e, Yarbay Ian Smith tarafından ise Ali Nadir Paşa'ya verilir. Ayrıca Türk yetkililer tarafından işgal sırasında kargaşa çıkmaması için önleyici tedbirler alınması, özellikle de Türk birliklerinin kışlalarında tutulmaları gerektiği bildirilir' ${ }^{4}$ Bu hareketlilik şehirde büyük heyecana yol açar. Morgan ve Smith'in hükümet konağının çıkışında dışarıda bekleyen kalabalık tarafından etrafları çevrilir. İçlerinden biri İngilizce olarak şunları söyler: “İngilizlerin, İzmir'in Yunan topră̆l olmasina müsaade etmemesi gerekir. Bunu kabul etmeyeceğiz, biz daha ölmedik. Burada büyük kötülükler yaşanacak, biz ölebiliriz fakat başkaları da ölecek"s. Hükümet konağ1 önünde bekleyen gençler Ali Nadir Paşa ile de karşılaşıp "Paşa ne yapmak lazımsa söyleyiniz yapalım. Bizi eli kolu bağll düşmana teslim mi edeceksiniz?" diye sorarlar ${ }^{6}$.

3 Giles Milton, a.g.e., s. 97.

4 Buğra İnal, "Bir İngiliz Subayının Gözünden İzmir’in İşgali ve Yaşananlar”, Büyük Taarruzun 90. Yıldönümünde Uluslararası Millî Mücadele ve Zafer Yolu Sempozyumu, Atatürk Araştırma Merkezi Yayınları, C II, Ankara, 2014, s. 1215.

5 F.O. 608/104/4, No: 112973, Amiral Calthorpe'nun 20 May1s Tarihli Raporu, Aktaran İsmail Ediz, Diploması ve Savaş İngiliz Belgelerinde Batı Anadolu'da Yunan İşgali, Atatürk Araştırma Merkezi Yayınları, Ankara, 2015, s. 151.

6 Haydar Rüştü Öktem, Mütareke ve İşgal Anıları, Haz. Zeki Arıkan, Türk Tarih Kurumu Yayınlar1, Ankara,1991, s. 66. 
Müslüman ahalinin önde gelenleri Yunan işgaline engel olmak için çare üretmeye koyulurlar. İzmir Müdafaa-i Hukuk-1 Osmaniye Cemiyeti'nin çatıs1 altında özellikle Türk Ocakları üyeleri ve Mekteb-i Sultani öğretmenlerinin içinde yer aldığı bir grup çeşitli toplantılarda işgale karşı yapılması gerekenleri tartışır. Bu arada Mekteb-i Sultani'de toplantılar devam ederken, Vali İzzet Bey ile görüşmek üzere bir heyet seçilir, görüşme sırasında heyetin endişelerine karşılık Vali; bir ilhakın söz konusu olmadığını, evlerine geri dönmelerini, hükümetin ülkenin haklarını ve Müslümanların çıkarlarının savunulmasına yönelik tedbirler alacağından emin olmaları gerektiğini bildirir? Vali ile görüşmelerden bir sonuç çıkmayınca Mekteb-i Sultani'de toplantı halinde olan grup bir takım kararlar alır: İşgale karşı koymamak, barışçıl yollarla direnmek için İlhak-1 Red Heyet-i Millîyesi diye anılacak bir kurul seçmek, protesto mitingi düzenlemek. Mekteb-i Sultani dışında bir toplantı da Türk Ocağı'nda yapılır. Türk Ocağındaki toplantıda Mustafa Necati: "Tehlike yaklaştı. Rumlar harl harll silahlaniyor ve bir şeyler bekliyorlar. Biz ise kalemle, muhtıra ve nutuklarla nümayiş ve alayişle iş görmeğe çalışıyoruz. Bu doğru değildir. Her ihtimale karşı bütün Türklügün silahlanması icab eder. Ona göre teşkilat yapmallyzz" önerisinde bulunur ${ }^{8}$. Ancak Mustafa Necati'nin teklifi arkadaşları tarafindan yeteri kadar desteklenmez. Bunun üzerine Necati, Heyet-i İdare Azalığı'ndan istifa eder. Diğer yandan Anadolu ve Duygu gazeteleri sahibi Haydar Rüştü, Hüsnü ve Osman Beyler ile İzmir'e üç dört gün önce gelmiş olan Miralay Kazım Bey olası işgale karşı direniş konusunu görüşmüşlerdir. Bu görüşmede Kazım Bey’in de onayıyla düşmana karşı silahlı direnişin İzmir haricinde mümkün olabileceği ve bunun için de eli silah tutanın İzmir'i terk ederek Ödemiş cihetlerine çekilmesinin icap edeceğinin rast gelen vatandaşlara telkin edilmesi kararlaştırılmıştır. Celal Bayar'ın Ödemiş’e gitmesi ve Gökçen Efe ile birleşerek düşmana karşı direniş hazırlığında olması bu kararda etkili olmuştur?.

Türk Ocağındaki toplantıda da İzmir halkının işgale karşı olduğunu göstermek için miting düzenleme kararı alınır. Maşatlıkta yapılacak olan mitinge yönelik birden fazla çağnı metinleri oluşturulur. Redd-i İlhak Cemiyetinin hazırladığı beyanname Haydar Rüştü Öktem'in onayıyla Anadolu gazetesi matbaasında basılır. Bu çabaların sonucunda Maşatlıkta büyük bir kalabalık

7 Selçuk Ural, Mehmet Okur, "Vali İzzet Bey’in Kaleminden İzmir'in İşgali”, A.Ü. Türkiyat Araştırmaları Enstitüsü Dergisi, S 17, Erzurum, 2001, s 269.

8 Haydar Rüştü Öklem, a.g.e., s. 63.

9 A.g.e., s. 66. 
toplanır, burada yapılan konuşmalarda Müslüman ahali Yunan işgaline karş1 direnişe çağrılır.

15 Mayıs sabahı İngiliz, Fransız ve Yunan savaş gemilerinin koruması altında Yunan birliği "Bölgedeki kanun ve düzeni sağlamak adına" İzmir'e çıkar. Bu sırada limanda bulunan Amerikan filosu da İtalyanları gözetlemekle meşguldür. İzmir'i işgal ile görevlendirilen Yunan birliklerinin komutanı Zafiriu, Leon gemisiyle Körfez'e gelir. Zafiriu gelir gelmez Yunan Averof gemisinin kaptanı Mavroudis'le birlikte Amiral Calthorpe'u ziyaret eder. İngiliz Amiral, Yunan subaylarını özellikle yerli Rumların gösterilerine engel olmaları konusunda uyarır. Ayrıca olası bir direnişe karşı Yunan askerlerinin karaya çıktığı esnada Osmanlı askerlerinin kışlalarına hapsedilmesi kararlaştırılır. Şehre giren Yunan birlikleri işgal sırasında olası bir direnişi engellemek için mümkün olduğunca hızlı hareket edecek, Türk ve Rum mahallelerinin aras1na girerek olası çatışmayı engelleyecektir. Bu doğrultuda Yunan kuvvetlerinin bir bölümünün demiryolu şirketi Pier'e, bir başka birliğinin Karantina'ya konuşlandırılması planlanmıştı. Üçüncü birlik rıhtıma yerleşecek ve böylece Müslümanların yaşadığı bölge Hristiyan bölgesinden ayrılmış olacaktı. Plana göre Averof kaptanı Mavroudis Karantina'ya çıkarma yapacağı için kışlanın önünden geçmesi gerekmeyecekti. Buna rağmen Karantina'da Türk kalabalıklar olduğu öğrenilince oraya çıkartma yapmaktan vazgeçildi. Karantina'da bir direniş hareketinin planlandığı hakkında ihbar alınması da bunda etkili oldu. Böylece gemideki askerler Yunan işgal güçlerinin komutanı Zafiriu'dan habersiz olarak rıhtıma çıkarıldı ve hükümet konağı ve kışlaya doğru yürümeye başladı. İngilizlere göre Zafiriu, Yunan birliklerinin kışlalardan uzak tutulması konusunda gerekli emirleri vermemiş Türk yetkililerini de konuyla ilgili bilgilendirmemişti ${ }^{10}$.

İzmir Metropoliti Hrisostomos karaya çıkan ilk Yunan taburunu takdis etti. İzmir çevresinden gelen yerli Rumlar, bayraklar ve çiçeklerle Efsun askerlerini karşılamaya gelmişti. Bu gelişmeler Türkler arasında büyük infial uyandırmaktaydı. Hatta USS Manley'in komuta subayı Robert Berry, Yunan askerlerinin gemiden disiplinsiz bir şekilde indiğini ve bu durumun kendisini dehşete düşürdüğünü belirtecektir. Berry’i şaşırtan bir diğer durum ise yerli

10 F.O. 608/104/4, No: 14241, Morgon'1n 20 May1s tarihli raporu, Rapor No: 21. Aktaran İsmail Ediz, Diploması ve Savaş İngiliz Belgelerinde Batı Anadolu'da Yunan İşgali, Atatürk Araştırma Merkezi Yayınları, Ankara, 2015, s. 158. 
Rumların askerlere yönelik şiddetli sevgi gösterileri olmuştu ${ }^{11}$. Pasaport'tan Konak Meydanı'na ancak bir saatte gelebilen Efsun alayı saat kulesi ve kışlay1 geçip Kemeraltı girişine geldiğinde bir veya bir kaç el silah sesi duyuldu. Bunun üzerine önce Yunan askerleri saat kulesi civarına çekilip siper alarak yaklaşık 45 dakika boyunca kışlaya, hükümet konağına ve alana bağlanan caddeler ile binalara ateş etmeye başladı. Yunan askerlerinin açtı̆̆ ateş sonucunda çok sayıda Müslüman hayatını kaybetmiş, şehirde yerli Rumların da katılımıyla yağma başlamış ve işgal büyük bir kaosa yol açmıştır.

\section{Osmanlı Belgelerinde "İlk Kurşun" ve Hasan Tahsin}

İşgalin ilk günü yaşanan olaylar Osmanlı ve uluslararası kamuoyunu uzun süre meşgul etmiştir ${ }^{12}$. Yunan işgaline yönelik tepki, devletin kurum ve kuruluşlarınca bir çok yayının neşredilmesine neden olur. Başta İzmir olmak üzere Batı Anadolu'da Yunan ordusunun neden olduğu can, mal kayıpları, resmi ve sivil binaların tahribi, yağma hareketleri, işgale karşı tepkiler, gösteri ve mitingler, toplantılar başta resmi yazışmalar olmak üzere çok sayıda rapor ve dokümana girmiştir. Birinci elden kaynak niteliği taşıyan bu dokümanlar arasinda “15 Mayls 1919'da Konak'ta neler yaşandı?" sorusuna cevap arayan birçok resmi rapor ve yazışma mevcuttur. Bu resmi yazışmalarda özellikle çatışmanın başlangıcı, yani "ilk kurşun" meselesi, bütün anlatının merkezine oturmaktadır. Her ne kadar "ilk kurşunun" kim ve kimler tarafindan atıldığ konusunda çeşitli yaklaşımlar olsa da hiç bir resmî metinde Hasan Tahsin ${ }^{13}$

11 Giles Milton, a.g.e., s. 102.

12 İzmir işgali sırasında ölen ve yaralananların sayısı tam olarak bilinmemesine rağmen, Türk belgelerine göre İzmir ve banliyölerinde öldürülen Türklerin sayıs1 2000'in üzerindedir. Engin Berber, "Yunan İşgali Geldikleri Gibi Gidemediler", NTV Tarih, S 4, İstanbul, May1s 2009, s. 32.

131918 y1l içinde İzmir'e yerleşen ve burada Hasan Tahsin Recep Bey olarak bilinen Osman Nevres'in yaşam öyküsü ile ilgili çok farklı veriler ortaya konmuştur. Selanik doğumlu olan Nevres Bey'in aile kökenlerinden, doğum tarihine, göz rengine hatta boyu ve dış görünüşü de dahil olmak üzere birçok konuda farklı bilgiler mevcuttur. Şemsi Efendi ve Fevziye mekteplerinde temel eğitimini tamamlayan Osman Nevres, İstanbul'a gelip Darülfunun'a kayıt olmuştur. II. Meşrutiyet'in ilanında sonra ise İttihat ve Terakki tarafından Paris'e tahsile gönderildiği bilinir. Burada 5 yıl eğitim gördükten sonra İstanbul'a dönmüş, 1914 yılının başında Balkan Komitesi üyeleri olan İngiliz Buxton kardeşlere suikast düzenlemesi için Hasan Tahsin kimliğiyle Bükreş’e gönderilmiştir. Suikast teşebbüsünden sonra yakalanmış ve 5 yıl hapse mahkum edilmiştir. 1916 yılının sonlarına gelindiğinde 2 yıldan fazla hapiste kaldıktan sonra Alman ordularının Bükreş’e girmesi üzerine kurtulmayı başarmıştır. İstanbul'a döndükten kısa bir süre sonra 1917'nin başında verem tedavisi için İttihat ve Terakki tarafından bu sefer İsviçre'ye gönderilir. 
veya Osman Nevres ismi, ilk kurşunu atan kişi olarak gösterilmemektedir. İşgal sırasında hükümet konağı ve kışlanın, Yunan askerleri tarafından basılmas1 ve bir çok subay ve memurun tutuklanıp Pasaport ve Alsancak limanındaki gemilere hapsedilmesi İzmir'deki sivil ve askeri Osmanlı bürokrasisini doğal olarak başlangıçta dağınıklığa itmiştir. Bürokrasinin çeşitli unsurları görevlerinin başına döndükten hemen sonra yaşanan gelişmeleri bütün ayrıntıları ile başta Harbiye Nezareti olmak üzere ilgili kurumlara raporlarla bildirmişlerdir. İşgal sırasında Kolordu Karargahını doğrudan hedef alan Yunan askerleri bir çok subayın ve askerin ölmesine yol açmıştı. Saldırının ardından kışlaya giren Yunan askerleri burayı yağma ederek başta 17. Kolordu Komutanı Ali Nadir Paşa olmak üzere subay ve askerleri tutuklayıp limandaki Yunan gemilerine götürmüştür. Serbest bırakıldıktan sonra görevine dönen Ali Nadir Paşa başından geçenleri ayrıntılı bir şekilde Harbiye Nezareti'ne aktarır.

20 Mayıs 1919 tarihli rapora göre Kolordu Karargahı'nın teslimi sırasında 7 kişinin şehit edildiği, yine karargâha mensup subay ve sivil memurlardan 51 kişinin durumunun meçhul olduğu belirtilmektedir. Raporda çatışmanın ilk başlangıcı üzerinde de durulmuş ve "ilk kurşunun” bir Rum tarafından atılmış olabileceği öne sürülmüştür:

"Yunan kıtaatı saat 11'den itibaren büyük bir Yunan bayrağı takılı uzun bir sırık omzunda kavmiyetçilerle yerli Rumlardan müteşekkil bir cem-i gafir kolbaşı ile kolun yanlarını ihata ederek alkışlar, 'Zito Venizelos' sedalarıyla kışlanın önünde mürura başladı... Kışla cephesini kamilen ona mülasık dükkan ve garnizonları geçerek sağa tramvay yoluna döndükten biraz sonra Rumlardan biri tarafindan olması pek muhtemel revolver endahtını müteakip Yunan askeri derhal kışlaya karşı mevzi alarak kışla cephesini mütemadiyen ve la-yenkati olmak üzere ateşe tutmuş ve yine Kışla karşısına vaz edilmiş bir hafif makineli tüfeği ateşlerine iştirak ettirmişlerdir" ${ }^{\prime 14}$.

Ayrıca kışlaya yönelik Yunan askerinin saldırısı üzerine "vakanın kasdi olduğuna tamamen kani olan" Ali Nadir Paşa, ateş kesildikten sonra nizamiye kapısına çıktıklarını ve burada "Haysiyet ve şeref ve namus-ı hükümet

Burada özellikle Prens Sabahattin ile temasından dolayı İstanbul'a geri çağrıldığı iddia edilmektedir.1918 yılında 6 ay İstanbul'da yaşadıktan sonra İzmir'e gelerek ticaretle uğraşacaktır. İzmir'de Sulh ve Selamet Cemiyeti'nin temsilciğini de yapan Hasan Tahsin bir süre sonra Hukuk-1 Beşer gazetesini çıkarır.

14 İzmir Fecayii, "1 İzmir'in Suret-i İşgali, Harbiye Nezareti ve Umum Jandarma Kumandanlığına Gelen Raporlar ve sair Vesikalar”, b.y., t.y., s.13-14. 
ve askeriyeyi payimal eden ve şimdiye kadar tarihin kaydetmediği cinayet ve fecayii ve harekete" maruz kaldıklarını belirtir. Ardından da Ali Nadir Paşa ve maiyeti ağır hakaret, saldırı ve yağma altında limandaki Yunan gemilerine götürülmüş, 18 Mayıs sabah saat dokuza kadar da alıkonmuştur.

Ali Nadir Paşa'nın raporu üzerine Genelkurmay Başkanı Cevat Paşa, Harbiye Nezaretine yazdığı tezkerede Kolordu Komutanı Ali Nadir Paşa için "idaresizliğinin dahl-ı küllisi olduğu kanaatindeyim" diyerek muhakeme edilmesini ister. Bunun üzerine Müşir Kazım Paşa riyasetinde Erkan-1 Divanı Harbi işi tetkike başlar. Muhakeme sırasında Erkan-ı Harp binbaşılarından Abdülhamit Efendi, 56. Tümen Kumandanı Kaymakam Hürrem Bey, Kurmay Yüzbaşı Gönenli Nazmi’nin ifadelerine başvurulur. Muhakeme sırasında 15 Mayıs 1919'da yaşananlar bütün ayrıntılarıyla ortaya dökülmesine karşın Hasan Tahsin ve "ilk kurşun" ile ilgili herhangi bir ifade dile getirilmez ${ }^{15}$.

15 Mayıs 1919 ile ilgili yazılmış bir diğer önemli metin ise şehrin en önemli mülki idare amiri olan Vali İzzet Bey'in işgalin üzerinden üç ay geçtikten sonra, 16 Ağustos 1919 tarihli kendi el yazıyla Fransızca kaleme aldığ1 yirmi altı sayfalık beyanattır. Beyanname, İtilaf Devletleri tarafindan oluşturulan ve İzmir işgali başta olmak üzere Yunanlıların Ege Bölgesi'nde gerçekleştirdikleri ihlalleri araştırmak amacıyla kurulan Müttefiklerarası Tahkik Komisyonu'nun incelemeleri sırasında iddiaların doğruluğunu ispatlamak için hazırlanmıştır. Komisyona sunulan beyanname de Vali İzzet Bey, işgal gününü tüm ayrıntılarıyla aktarır ve özellikle meseleyi "ilk kurşuna" getirir. Kesinlikle hükûmet konağından ve halkın arasından Yunan askerine ateş açılmadığını vurgular, ardından da ilk silahı atanın kendisi açısından meçhul olduğunun altını çizer:

“ilk kurşunu sıkanın kim olduğunu bilmiyorum. Çünkü o anda engellendim, konakta kuşatıldim ve bütün gün boyunca torpido gemisinde tutuklu kaldım. Daha sonra bunun bir Yunanlı olduğunu öğrendim. Başkaları da zenci biri olduğunu iddia ediyorlardl. Fakat yaygın olan iddialara göre onun bir Yunanl olması gerekir. Müslüman halkın ve Osmanlı askerlerinin sokaklarda Yunanlıların üzerine ateş ettiklerini

15 Y1llar sonra Fahrettin Altay, Belleten dergisinin 89. Sayısında "İzmir Faciasının Muhakemesi” başlığı altında işgal sırasında kolordu kumandanı olan Ali Nadir Paşa'nın muhakeme fezlekesini değerlendirir. Daha da ötesi Fahrettin Altay makalenin sonunda işgal günü hayatını kaybedenleri rahmetle anarken özellikle Albay Süleyman Fethi Bey'in adını öne çıkartır. Fahrettin Altay, "İzmir Faciasının Muhakemesi”, Belleten, C 23, S 89, Y1l 1959, s. 156. 
sanmiyorum... Kışladan Yunan askerlerine ateş edildiği iddia edilmektedir fakat ben bunun doğrulayamam. Fakat kesin olarak ve de açıkça ifade edebilirim ki ne Konak'tan ne de halkın arasindan işgal ordulartnın üzerine ateş açılmamışıtır"16.

Görüldüğü gibi tam da çatışmanın başladığı noktada bulunan hükümet konağının ve kışlanın yaşananlara bizzat şahit olan amirleri, aynı zamanda konuyla ilgili idari soruşturma açmaya en yetkili iki bürokrat olan İzmir Valisi ve Kolordu Komutanı'nın raporlarında “ilk kurşunu” Hasan Tahsin veya başka bir Müslümanın attığına dair bir ifade geçmez.

"İlk kurşunun" kim tarafından ve niçin atıldığının anlaşılamadığını ifade eden diğer bir resmi metin de İzmir Heyet-i Tahkikiye azasından Kaymakam Arif Bey'e aittir. Arif Bey de Vali İzzet Bey ve Kolordu Komutanı Ali Nadir Paşa gibi "ilk kurşunun" Yunanlılar tarafından kışlaya saldırmak için fırsat olarak kullanıldığı kanaatindedir:

"Yunan Efsun alayı kolbaşında üç metre tulunda bir Yunan bayrağ açıllmış olduğu halde yürüyüs nizaminda mahfel-i askeri önünden geçerek kuşlanın kapısı önünde durdu ve bir iki dakika sonra da yine Kemeraltı cihetine yürüyüşüne devamla kışlanın şarkında ve ittisalindeki kiraathane önünden Karantina Caddesi'ne doğru ilerleyerek tevakkuf etti. Yerli Rum ahalisi bu Efsun alayının her tarafinı kuşatarak "Zito" sedalarıyla ve Rumca birçok elfaz ile mezkur alayı efradını tehyiç etmekteydiler. Bu sirada bir revolver sesi işitildi. Fakat kimin tarafindan kimin üzerine ve ne için atıldiğı anlaşılamadı. Anlaşılan cihet bu silahin ne sebeb-i endaht ve ne de hedef-i isabeti tahkike lüzum görülmeksizin Efsun alayının klşla ve hükümete karşı ateş etmeye imkan gören kitaatının hemen münasip surette mevzi alarak şiddetli bir ateş açması ve bizim taraftan katiyen mukabele görmeyen bu ateşin bir çeyrek saatten ziyade imtidad etmesi ve ateşe birkaç Yunan makineli tüfeğinin dahi iştirak etmesi ve bir Yunan sefinesinin de kışlayl topa tutmak üzere kışlaya takarrüb eylemesi idi" ${ }^{\prime 17}$.

16 Başkanlık Osmanlı Arşivi, DH.İ.UM. EK, 66/12. Ayrıca Bkz. Selçuk Ural, Mehmet Okur, "Vali İzzet Bey'in Kaleminden İzmir'in İşgali", A.Ü. Türkiyat Araştırmaları Enstitüsü Dergisi, S 17, Erzurum, 2001, s 267-274. Mehmet Karayaman, "İzmir Valisi İzzet Bey'in Kaleminden İzmir'in İşgali”, Çağdaş Türkiye Tarihi Araştırmaları Dergisi, VI/15, Güz/2007, s. 12.

17 İzmir Aydın Ayvalık ve Havalisi Yunan İşgali Hakkında Makamat-ı Askeriyeden Mevrud Raporlar, İkinci Kitap, Matbaa-i Askeriye, Dersaadet, 1335, s. 10-11. 
İşgal sırasında Yunan askerleri tarafindan tutuklanarak Leon torpidosuna götürülen Osmanlı bürokratları arasında yer alan İzmir Rüsumat Başmüdürü Agah Efendi de yaşanan kargaşa hakkında bilgi verir. Tutuklandığı sırada saldırıya uğrayıp, fesi parçalanan ve "Zito Venizelos" diye bağırmaya zorlanan Agah Efendi'nin raporunda "ilk kurşunun" atılma anı şu ifadelerle yer alır: "Yunan asakiri trampet çalarak klşlaya doğru yürümeye başladılar. Tarifi nakabil büyük bir elem, fakat yine soğukkanla şu manzarayı uzaktan görüyor idik. Asakirin bir hayli miktarı geçtikten sonra uzaktan işitilen bir el silah sesini müteakip ne kadar sivil ahali ve asker geçmis ise bunların gayr-ı muntazam bir surette ve kemal-i tehalükle kaçıştıkları görüldü̈̆̈̈ gibi silah sesleri de tezayüd ettiğinden kapı ve pencereleri mükemmelen kapayarak hadisa(ta) muntazır olduk"18.

Konuyla ilgili başvuru niteliği taşıyan en önemli belgelerden biri ise 20 May1s 1919'da Harbiye Nezareti'ne sunulan İzmir Jandarma Alay Kumandanı Kaymakam Süreyya Bey'in kaleme aldığı rapordur. Bu raporu önemli kılan ise Süreyya Bey ile Mıntıka Müfettişi Yüzbaşı Ziya Efendi’nin hadiseyi pencereden izliyor olmasıdır. Rapora göre; “...askerlerin önünde elinde bir tabanca olan bir sivil Rum muhterizane ilerleyen Yunan askerini teşci etmekteydi. O esnada kışlık kapısı karşısında toplanmış olan İslamlardan mürekkeb gayr-ı müsellah on onbeş kişilik kadar bir kitlenin üzerine bir efzun neferi hücum ederek kitle-i mezkureyi dipçik ve süngü ile darb ve taarruz ettiği slrada bir el silah endaht ve bunun üzerine Yunan askerleri tarafindan ateş..." açılmıştır ${ }^{19}$. Süreyya Bey'in aktardıkları farklı bir anlatıya işaret etmektedir, bir Efsun askerinin silahsız Müslüman bir gruba dipçik ve süngü ile saldırdığ1 sırada bir el silah sesi duyulmuş ve bunun üzerine Yunan askerleri tarafindan ateş açılmıştır. Bütün bu ayrıntılara rağmen Süreyya Bey de ilk silahı ateşleyenin kimliği hakkında bilgi verememektedir. Raporun devamında subayların tutuklu olarak Kordon istikametine götürüldükleri, yerli Rumların fiili saldırısına maruz kaldıkları, hatta Rumların kafileyi imha edeceği sırada insaniyetperver bir Fransız zabitinin kılıç çekerek saldırganların üzerine yürümesiyle hayatlarının kurtulduğu belirtilir. Tutukluların vapura götürülmesiyle tekrar kötü muamele başlamış ve Yunan askerlerinin hakaret ve fiili saldırısına uğramışlar, vapurda askerler ile ahali birbirinden ayrılmış, iki gün boyunca tutuklu kaldıktan sonra tahliye edilmişlerdir.

18 A.g.e., s.4.

19 A.g.e., s.22-23. 
Mıntıka Müfettişi Yüzbaşı Ziya Bey de, "ilk kurşun" konusunda yerli Rumları işaret etmektedir. Jandarma Kumandanlığına gönderdiği raporda anlattıklarına göre; etrafında bazıları revolverleri olan sivil Rumların bulunduğu Efsun taburu, kışlayı sükunet ve intizam ile geçip köşeyi döndükten ve kışla ile arasında 300 metre kadar bir mesafe meydana geldikten sonra nereden atıldığ 1 anlaşılamayan ve en kuvvetli ihtimal müfreze etrafından bulunan revolverli kişilerden birisinin belki de kendi ihtiyarı dışında tabancasının patlamasıyla olaylar başlamıştır. 15 Mayıs günü ve sonrası ile ilgili bir çok ayrıntı içeren Ziya Bey'in raporunu konumuz açısından önemli kılan ise Hasan Tahsin'den bahsediyor olmasıdır. Albay Süleyman Fethi Bey, Başkatip Şükrü, Kolağası Necati Bey gibi isimler şehit zümrenin başta gelenleri olarak sayllırken bu isimlere Hasan Tahsin de şu ifade ile dahil edilmiştir: "Hukuk-ı Beşer gazetesi sahibi olup Kordon üzerinde parça parça edilmek suretiyle şehit edilen Tahsin Recep Bey..."

Hasan Tahsin'in isminin geçtiği ender metinlerden biri de 13 Haziran 1919 tarihli İzmir Müdafaa-i Hukuk-1 Osmaniye Cemiyeti tarafından Osmanlı sulh murahhaslarından Tevfik Paşa'ya takdim edilen muhtıradır. Söz konusu raporda ise Hasan Tahsin'in evinde hayatını kaybettiği yazılır. Ayrıca işgal sırasında hayatını kaybedenlerin başında ilk olarak Miralay Fethi Bey, Ahz-1 Asker Heyeti mümeyyizlerinden Nadir Bey, Alay Katibi Fahreddin Efendi ve Ahz-1 Asker levazım dairesinden Ahmet Bey'in isimleri verilir.

İzmir Müdafaa-i Hukuk-1 Osmaniye Cemiyeti Yunan işgaline karşı sivil direnişin en önemli merkezi konumundayd $1^{21}$. Dolayısıyla örgütlü bir yap1 olarak bilgiye ulaşma potansiyelinin büyüklüğü raporda yer alan ayrıntılarda kendini gösterir. Raporda aktarılanlara göre Sanayi Mektebi talebesinden 28 numaralı İhsan Efendi Ziraat Bankası önünde Efsunlar tarafından boğazlanmıştır. Polis santral memurlarından Fahri ve Refik Hüseyin Efendiler vazifeleri başında asker tarafindan bir sureti vahşiyanede şehit edilmiştir. Urla Polis komiseri Giritli Hüseyin Efendi Ziraat Bankası önünde parça parça edilmiştir. Hukuk-1 Beşer gazetesi sahip ve Ser-muharriri Tahsin Recep Bey ikametga-

20 Raporun içeriği için Bkz. Celal Bayar, Ben De Yazdım, C 6, Sabah Kitapları, İstanbul, s. 198. Celal Bayar aynı eserinde "İşgal Günü Patlayan Silah, Kim Attı?” başlığı altında konuya yer ayırmış, Ahenk gazetesi başyazarı Şevki Bey'in kendisine yazdığı mektuba dayanarak "ilk kurşun" konusunda Saatçi Aziz Efendi’nin ismini işaret etmiştir. Celal Bayar, a.g.e., s. 50-51.

21 Bakınız. İzzet Öztoprak, İzmir Müdafaa-i Hukuk-ı Osmaniye Cemiyeti, Atatürk Araştırma Merkezi Yayınları, Ankara, 2014. 
hında şehit edilmiştir. Köylü gazetesi mürettiplerinden iki masum yavrucak parçalanmıştır. İzmir inzibat askeri memurlarından Cuma ovasında eşraftan Ahmet A ğa'nın mahdumu Refik Efendi tüyleri ürpertecek bir vahşetle boğazlanmıştır. Hükümet karşısında askeri otelinde misafir erkek, kadın ve çocuk olmak üzere 8 kişi parçalanmıştır. Süvari polislerinden Halit Efendi feci bir şekilde şehit edilmiştir. Ayatzigonadan Manisalı Sağır Hasan ve Ispartalı Koviyos Ahmet umumhaneci İskona Mariyanti'nin oğlu tarafından şehit edilmiştir. İzmir Pasaport kayıkçılarından 45 kadar Müslüman boğularak boğazlarına zincir bağlanmak suretiyle şehit edilmiş ve denize atılmıştır. Tilkilik Maliye Tahsil Şubesi Memuru Nuri Bey, Köylü matbaası önünde elliye yakın süngü darbesiyle şehit edilmiştir. Sabık polis memurlarından ve İzmir'in Dolaplı Köyü mahallesinden Giritli Ahmet Efendi asker tarafından parça parça edilmiştir. Eşref Paşa mahallesinden Sandalcı Tatar Hüseyin boğazlanmıştır. Son derece ayrıntılı bilgiler içeren raporda soyulan ve yağma edilen dükkan ve işyerlerinin isimleri tek tek siralanır ${ }^{22}$.

14 Mayıs günü İtalyan Konsolosluğu'ndaki arkadaşlarından İzmir'in Yunan ordusu tarafından işgal edileceğini ilk duyanlardan olan ve ardından birçok tanıdığını harekete geçirmeye çalışan Maliye müfettişlerinden Muvaffak Bey tarafindan tanzim kılınan rapora göre ise "ilk kurşun" yerli Rumlar tarafindan atılmıştır. Yunan askerleri Hükümet Konağı ile kışlanın önünden geçerken yerli Rumların tahriklerine rağmen sükûnetini korumaktadır. Yunan askerleri kışladan iki yüz metre kadar ilerledikten sonra iki silah atılır. Daha sonra hastanede tedavi altında bulunan bir polis neferinin verdiği bilgiye göre atılan bu iki el silahla Komiser Hüseyin Efendi yerli Rumlar tarafindan öldürülmüştür: "El-yevm hastanede taht-ı tedavide bulunan bir polis neferinin ifadesine nazaran teyakkuz ve faaliyeti hasebiyle Rumlarn husumetini celb etmiş olan Komiser Hüseyin Efendi yerliler tarafindan atılan bu kurşunlarla şehit edildi”23.

$\mathrm{Bu}$ arada işgal günü İzmir'de bulunan ve olaylara şahit olmuş birçok kişi İzmir'i terk etmiş, civar illere giderek gördüklerini, duyduklarını aktarmışlar ve bu bilgiler de resmi raporlara girmiştir. M. Şefik Bey imzalı 22 Mayıs 1919 tarihli Aydın 57. Tümen Kumandanlığından gönderilen rapor olay günü Kışlada bulunan ve Yunan askerleri tarafindan tutuklanan 17. Kolorduya mensup

22 İzmir Fecayii, "1 İzmir'in Suret-i İşgali, Harbiye Nezareti ve Umum Jandarma Kumandanlığına Gelen Raporlar ve sair Vesikalar”, b.y., t.y., s.28-32.

23 A.g.e., s. 39. 
Matbuat Sansür Müdürü Yüzbaşı Faik ve memuru Üsteğmen Zekai Efendilerin yazılı ifadelerini içermesi bakımından ilginçtir. Görgü tanıklarının anlattıklarına göre; "Yunan alayı hükümet dairesi arasındaki meydana geldiklerinde klşladan bir ateş patlatılmamış iken sebepsiz yere kışla üzerine Yunanlılar ateş açmişlar ve on dakika devamdan sonra 15 kadar subay ve üst rütbeli subay sebepsiz yere şehit ve 40 kadarı da yaralanmıştır"24.

Öte yandan İzmir'in işgali 23 Nisan 1920'de Ankara'da açılan Büyük Millet Meclisi'nin de gündemine gelir. Bu konuda söz alanlar arasında üç kişinin ismi dikkat çeker. İşgalden kısa bir süre önce İzmir'den ayrılıp Ödemiş’e geçen ve burada Millî Mücadele'nin örgütlenmesinde rol oynayan, İttihat ve Terakki Cemiyeti İzmir Katib-1 Mesulü olan Mahmut Celal (Bayar), Adana Fransız işgaline uğradığında İttihatçı kimliğinden dolayı şehri terk edip İzmir'e gelen ve işgal günü yaşananlara bizzat şahit olan İsmail Safa Bey, işgal sırasında İzmir'de bulanan Türk direnişinin önemli isimlerinden olan Mustafa Necati. Ancak her üç kişi de Hasan Tahsin'den söz etmek bir yana "ilk ateşin" menşei hakkında herhangi bir bilgi de vermemiştir. TBMM'nin 15 Mayıs 1920 tarihli oturumunda İzmir'in işgalinden dolayı Ankara ahalisi tarafından gönderilen bir protesto metni gündeme alınmış ve Meclis'e takdim edilen bu metin genel kurulda okunduktan sonra Saruhan milletvekili Mahmut Celal Bey söz almıştır. Celal Bey konuşmasında "ilk kurşundan" bahsetmediği gibi Yunan ordusunun doğrudan saldırıya geçtiğini söylemektedir: "İzmir, efendiler 15 Mayıs yevmi meşumunda işgal edilmiştir. Yunan ordusu o güzel İzmir'in güzel kordonuna ayak bastığı zaman bana bir ecnebi arkadaşımın dediği gibi, kudurmuş bir köpek (şiyen anraje) gibi milleti İslâmiyeye saldırdl. Orada ne ulemanın haysiyeti ve ne eşrafin şerafeti gözetildi ve ne ahalinin hukuku muhafaza edildi'. Konuşmasının devamında sözü, İzmir'in işgal günü söz konusu olduğunda ilk akla gelen isim olan Miralay Fethi Bey'e getirir ve şunları ifade eder: "Yunan askerleri Kışlaya girdiler ve karşılarına çıkanları sormadan süngülediler. Orada, muhterem kumandanlarımıdan Miralay Fethi Bey muvacehelerine çıktığl zaman kendisine 'Kralımız namına yemin edeceksin, zito diye bağıracaksın' dediler. 'Yaşasın padişahım ve milletim' diye bağırdl ̆̆g için düşman süngüleri ile sinesi delindi ve alkanlar içerisinde yere serildi" ${ }^{25}$.

24 İzmir Fecayii, s. 27-28.

25 ТВМм Zabıt Ceridesi, Devre:1, Cilt 1, İçtima Senesi: 1, Onaltıncı İçtima, (15.5. 1336 Cumartesi), Ankara, TBMM Matbaas1, 1959, s. 306-308. 
Celal Bayar'dan sonra Mersin mebusu İsmail Safa Bey söz alır, İsmail Safa Bey, Celal Bayar'dan farklı olarak işgal günü İzmir'dedir: “Ben, İzmir faciası tarihin yüzünü kızartırken İzmir'de idim. Yani bu kanlı facianın şahidi oldum. Halâ bu kanl, hunin ve meşum hatıra dimağımda en şedit bir ıstırap uyandırıyor. Onun için İzmir'de gördüklerimi, İmir'de gördüğüm facianın ateşi harapkârisini burada sizlere anlatmak istiyorum". İsmail Safa Bey'in aktardıklarına göre direnişçiler; Yunan işgalinin gerçekleşeceğinin kesinleşmesi üzerine şehirde harp etmenin çok acı ve felakete yol açacağını ileri sürerek müdafaayı dışarıda yapmayı kararlaştırır. Ancak son bir çaba olarak İzmir limanında İngiltere, İtalya, Amerika ve Fransa zırhlılarının bulunmasından dolayı bütün Müslümanlar rihtıma giderek İzmir'de yüzbinlerce TürkMüslümanın olduğu göstermek istenir. Avrupa bu hakikat karşısında ihtimal utanır, sakınır, bir faciaya, bir kıtale meydan vermez diye ümit edilir. Geceden bütün mahallere haber salınır ve halk akın akın Maşatlığa toplanır. Aslında hiç kimse ne yapacağını ve yapılması gerektiğini bilmiyordur. Sabah olunca rihtıma gidilse de, bir vakaya sebep olur kaygısı baskın çıkmış ve bir kaç kişinin Amiral Calthorpe'a gönderilmesi kararlaştırılmıştır. Bu karar üzerine üç murahhas Yunan işgalinin medeniyet için, tarih için, beşeriyet için bütün insanlık için büyük bir faciaya yol açacağını anlatmak için zırhlıya giderek Amiral ile görüşür. Amiral'ın cevabı "Siz mağlup olduğunuzu bilmiyor musunuz?" olur. Yunan ordusunun rıhtıma çıktığı sırada bir fenalık ile karşılaşmamak için Müslüman ahali hükmet konağı civarına toplanmıştır. Bu arada İsmail Safa'nın verdiği bilgilere göre Yunanlılar iki üç aydan beri Metropolithaneye vapurlar ile silah ve elbise taşıyor, Rumlar Kiliseye sivil girip diğer taraftan silahla birlikte asker olarak çıkıyordur.

Konuşmasının bundan sonraki kısmında; arkalarındaki Rumlarla birlikte Yunan askerlerinin işgal amacıyla kışlaya doğru hareket ettiğini belirterek konuyu ilk silahın patlamasına getirir: "Yunan askeri, önünde Rumlar, büyük bir kafile halinde hükûmetten döndüler, kışlaya gelecekler. Bu arada bir silah patladl. Silah patlar patlamaz, Yunan askeri süngüleri silahın üzerlerinde olduğu halde geliyorlardl, sokakta kimi gördülerse süngülediler. Halk tabî bu silah patlar patlamaz büyük bir tevahhuş gösterdi. Bir kısmı Maşatlĭga, bir kısmı İslâm mahallâtına çarsı içerisine doğru omuz omuza kaçmaya başladılar. Bunları arkalarından bir yaylım ateşiyle taradılar" ${ }^{26}$. İlk silah patla-

26 TBMM Zabıt Ceridesi, Devre:1, Cilt 1, İçtima Senesi: 1, Onaltınc1 İçtima, (15.5. 1336 Cumartesi), Ankara, TBMM Matbaas1, 1959, s. 309-312. 
dıktan sonra Yunan ordusu esas olarak içerden herhangi bir müdafaa olmamasına hatta bir zabit teslim bayrağı çekmesine rağmen arkadan ve önden kışlayı ateşe tutmuştur. Kışlaya girdikten sonra ise yetmiş seksen kadar zabiti elleri yukarda rıhtıma doğru kafile halinde ikişer ikişer sevk etmeye başlarlar. Rıhtım yolu üzerindeki evlerin balkonundan Rumlar kafileye ateş eder. Leon zırhlısından da kafile üzerine ateş açılmış, ateşe muhafız neferleri de katılınca ve kafiledekilere süngüleriyle saldırınca doksan zabitin otuzu hayatını kaybetmiştir. İsmail Safa, bütün olaylar esnasında beş bin Türk'ün hayatını kaybettiğini de belirtir.

TBMM'nin çeşitli oturumlarında defalarca söz alan Saruhan milletvekili Mustafa Necati de İzmir'in işgali gündeme geldiğinde Süleyman Fethi Bey'in ismini anmadan geçmemiştir. 9 Temmuz 1921 tarihli oturumda: "Efendiler, bütün Hristiyan milletlerin donanmaları İzmir körfezinde bulunurken düşman süngüsü; düşman gemileri önünde Türk kumandanı Miralay Fethi Beyi süngüledi" ifadeleri ile başladığı konuşmasına İzmir'de işgal günü üç dört bin Müslümanın öldürüldüğünü belirterek devam etmiştir ${ }^{27}$. TBMM'nin 13 Eylül 1922 tarihli oturumunda ise İstanbul Mebusu Ali Riza Bey'in, İzmir'de Yunanlılar tarafından şehit edilmiş olan Miralay Süleyman Fethi Bey'in ailesine İzmir'in istirdadı münasebetiyle taziyet telgrafı çekilmesine dair takriri ele alınmıştır. Mustafa Necati yaptığı konuşmada "Efendim, İzmir işgalinde bulunduğum için Süleyman Fethi Bey'in sureti şahadetine tamamıyla vâkıfim" diyerek Süleyman Fethi Bey’e "yaşasın Venizelos" diye bağırmasını teklif ettiklerini ancak Fethi Bey'in buna karş11ık "Bir Türk kumandanı bir Türk Miralayı kendi kumandanlarından ve kendi milletinden başkasının yaşamasını temenni etmez" dediğini ve Yunan süngüleri karşısında teklifleri reddettiğini belirtmiştir. Mustafa Necati konuşmasını şu sözlerle bitirir: "Bu zatın yaptı̆̆ bu fedakârlık kalpler üzerinde iyi tesirat icra etmiş ve bu defa inkılabın âmili hakisi olmuştur. Bu itibarla Fethi Bey'in namının bu sevimli günde tezkârını Meclisi Âli için şerefli addeder ve ailesine beyant taziyet edilerek teessürattmizın tebliğini de bilhassa rica ederim". ${ }^{28}$

27 TВMM Zabıt Ceridesi, Devre 1, Cilt 11, İçtima Senesi 2, Kırksekizinci İçtima, (9.7.1337), Ankara, TBMM Matbaas1, 1958, s. 216.

28 TBMM Zabıt Ceridesi, Devre:1, Cilt 1, İçtima Senesi 3, Yüzbirinci İçtima, (13.9.1338), Ankara, TBMM Matbaası, 1960, s. 13. 


\section{Basında Hasan Tahsin ve "İlk Kurşun" Meselesi}

İşgalin ardından İzmir basını sansür altında olmasına rağmen işgal ile ilgili haberleri kısıtlı da olsa aktarmaya devam eder. İşgale karşı yayın yapan ve tepkileri sayfalarına aktaran 17 Mayıs tarihli Ahenk gazetesi bir yandan Yunan İşgal Kuvvetleri Komutanlı̆̆ı'nın tebligatını yayınlarken diğer yandan da işgal sırasında tutuklananların tahliyelerinin başladığını bildirir. Ayrıca işgal sırasında maktul düşenlerinin cesetlerinin ise Gureba-yı Müslimin Hastanesi'nin karşısındaki Cemal Paşa Konağı'nda bulunduğunu ve akrabalarını yitirenlerin oraya başvurması gerektiğini beyan eder. Ahenk gazetesinin 18 Mayıs tarihli sayısında ise işgalin ülkeyi "feci bir matem içinde bıraktığı" dile getirilirken, Hasan Tahsin'in de "kargaşalık esnasında şehit düştüğü" ifade edilir, hiç bir şekilde "ilk kurşunu” Hasan Tahsin'in attığına dair bir bilgi veya imaya yer verilmez: "Hukuk-ı Beşer refikimizin ser muharriri Hasan Tahsin Recep Bey'in de kargaşalık esnasında şehit düştügüüü kemal-i teessüfle öğrendik. Cenab-i Allah gani rahmet eylesin..."29.

Kargaşanın nasıl başladığı ise Islahat gazetesinden Sabitzade Emin Süreyya tarafından aktarılır. Vali İzzet Bey’e yönelik eleştiriler üzerine Valiyi savunmak için kaleme aldığı yazısında, olaylar sırasında Vali'nin odasında bulunduğunu belirtir. Emin Süreyya'nın halkın galeyanda olduğunu ifade etmesi üzerine İzzet Bey önlem alması için polis müdürü Fikri Bey’e emir vermiş ancak Fikri Bey'in "Ifa-yı vazifeden acizim" demesi üzerine ise Vali, Kolordu Komutanı Ali Nadir Paşa”ya "Mikdar-ı kafi süvari müfrezesinin izamını" telefonla beyan etmiştir. Kışlanın bir kapısından çıkan süvariler emir telakki etmek üzere hükümete girerken, diğer taraftan, Yunan askerleri hükümet civarındaki kahvenin önünden geçmektedir. Bütün bu olayları defterdarın odasından izleyen Sabitzade Emin Süreyya kargaşanın başlangıç anını şu sözlerle aktarır: "Bu esnada meçhul bir semtten, patlayan silah sedası hadisenin vukuuna sebebiyet vermiştir"30.

19 Mayıs 1919'dan itibaren İzmir'de yaşanan hadiseler İstanbul bas1nında da yer almaya başlar. Tasvir-i Efkar gazetesi İzmir'in işgalinin bütün memlekette heyecan ve üzüntü yarattığından söz eder ${ }^{31}$. 20 Mayıs tarihli Vakit gazetesi işgal günü yaşananları aktarırken ilk olarak Yunan askerleri ve Rum-

29 Ahenk, 18 Mayıs 1919.

30 Sabitzade Emin Süreyya, “Tarihi Bir Şahadet Vali İzzet Beyefendi Hakkında”, Islahat, 27 Mayıs 1919.

31 Tasvir-i Efkar, 19 Mayıs 1919. 
lar tarafından silah kullanılması üzerine çatışmanın başladığını yazar: "İşgal sırasinda Yunan kitaatı ve bunlara peyrev olan yerli Rumlardan mürekkep bir cemm-i gafir tarafindan... Nümayişler devam ettiği sirada daire-i hükümete gelen Yunan kutaatı ve yerliler tarafindan silah istimal edilmis ve bunu müteakip müsademe başlamıştı" "32. Sabah gazetesinin haberinde de benzer bir açıklama söz konusudur ve yazılanlara göre ilk ateşi Yunanlılar açmıştır. Habere göre; önünde Yunan bayrağı taşıyan yaşlı bir Rum'un bulunduğu Yunan müfrezesi daireyi hükümet köşesinde görünmüş ve orada hükümetten izahat bekleyen Müslüman ahaliye ateş açılmış, Yunanlıların açtığı bu ateş üzerine İzmir'de o kanlı hercümerç başlamıştır ${ }^{33}$.

Bu arada İstanbul gazetelerinde Hasan Tahsin'in kaybından ilk olarak 24 Mayıs 1919 tarihinde bahsedilir. Ancak bu yayınların hiçbirinde Kordon'da "ilk kurşunu" atanın Hasan Tahsin olduğu ifade edilmez. İkdam gazetesi İzmir'den gelen bir mülteciye dayandırdığ 1 haberinde "Ahz-ı Asker Fethi, Hukuk-ı Beşer sahibi Hasan Tahsin Recep, tüccardan Bakırcızade Hafiz Sabri, otuzu mütecaviz yüksek rütbeli zabitan şehit edildi..." ${ }^{34}$. Ardından Tasvir-i Efkar gazetesi 26 Mayıs 1919'da Hasan Tahsin'in resmini de yayınlayarak altına şunları yazar: "Dünkü nüshamızda İzmir gazetelerinden naklen İzmir işgali esnasında şerbet-i şehadeti nuş eylediğini yazdiğımız Tahsin Recep Bey merhumun resmini ber veçhi bala vaz-ı enzar-l teessür eyliyoruz... Merhum Hasan Tahsin Bey, Balkan Harbi esnasında düşmanlarımızı müdafaa etmiş olan Meşhur Buxton biraderlerine karşı Romanya'da istimal-i silah eylemiş ve ahiren İzmir'de Hukuk-ı Beşer unvanla gazeteyi neşr eylemeye başlamıştı" ${ }^{35}$.

İstanbul basınında İzmir işgali ile ilgili en geniş yayınlardan biri 25-26 Mayıs 1919 tarihli Sabah gazetesinde neşredilmiş ve "İzmir Nasıl İşgal Edildi” başlığı altında “Dün İzmir'den gelen ve hadiseyi işgali bizzat görmüş olan bir zatın kaleme almış olduğu notlar... ” yayınlanmıştır. Notlar 14 Mayıs 1919 Çarşamba günü Amiral Calthorpe'un İzmir'e gelişiyle başlar. Vali İzzet Bey ile Amiral arasındaki görüşmenin içeriği aktarıldıktan sonra işgale karşı tepkiler üzerinde durulur. 15 Mayıs sabahı yaşananlar ise şu şekilde aktarılır:

32 Vakit, 20 May1s 1919.

33 Sabah, 22 May1s 1919.

34 İkdam, 24 Mayıs 1919.

35 Tasvir-i Efkar, 26 May1s 1919. 
“Kışla'nın işgalini hükûmet konağının balkonundan görmek üzere hükümete gittim. Bu sirada Yunan askeri her tarafinda yerli Rumlardan mürekkep bir kafile arasında kışla önünden geçiyor, tramvay caddesine sapiyordu. O sirada vuku bulan bir kargaşalıkta silahlar patladı. El bombaları atılmaya başlad. Askerin başındaki zabit seri bir kumanda ile ateş emri verdi. Askerler hemen yere yatarak şiddetli ateşe başladl. Arka taraftan gelen mitralyözlerle de devamlı ateş açılarak hükümet konağı, kışla ve civarı kurşun yağmurları altında kaldı. Daire-yi hükümette bulunan memurin ve dişarldan gelmiş olanlar yarım saat kadar ölüm tehlikeleri içerisinde korkunç dakikalar geçirdi... Hükümet konağından beyaz bir bayrak asıld, süngülü askerler içeriye girerek, hepimizi bir yere topladı. Fesler yerlere atılarak çiğnendi, 'eller yuka$r l$ ', 'Zito Venizelos' nidaları hükümet konağını çınlattı. Vali, defterdar, polis müdürü, jandarma kumandanı, mektupçu ve sair memurin zabıtan hükümette bulunan eşraf, gazeteciler ve sair hep başlar açı eller kalkik bir kafileyi azime süngülü asker marifetiyle dlşarlya sevk olundu..."

Ardından kafileye hareket emri verilir ve Kordon yoluyla giderken Gümrük önüne gelmeden durdurulur, içlerinden birisinin Yunan zabitine Vali İzzet Bey'i göstermesi üzerine liman reisi tarafindan Vali ve mahdumu kafileden ayrılır. Zat'ın aktardığına göre; Müslümanlardan 400'ü aşkın kişi hayatını kaybetmişti. Gümrük altından Atpazarına kadar bütün çarşı dükkanlar kırılarak yağma edilmiş, Köylü matbaası darmadağınık bir hale getirilmişti ${ }^{36}$.

Öte yandan 2 Haziran 1919 tarihli İkdam gazetesi “İzmir'in Yunanlılar tarafindan suret-i işgali muhtelif şekillerde tasvir ve kayd edildi. Vekayi-yi mezkure hakkında en sahih malumatı alabilmek üzere esna-i işgalde İzmir'de Kolordu Kumandanliğında bulunan ve ahiren maiyeti ile birlikte şehrimize avdet eden Nadir Paşa 'ya müracaat eyledik" diyerek o sırada İstanbul'da bulunan Ali Nadir Paşa ile gerçekleştirilen mülakatı yayınlar. "İzmir'in İşgalinin Hakiki Safhaları Hakkında Malumat....” başlığı altında Nadir Paşa'ya kargaşanın nasıl başladığı sorusu da yöneltilir. Nadir Paşa ise verdiği yanıtta Yunan askerleri tramvay yoluna döndükten biraz sonra Rumlardan biri tarafindan olmas1 pek muhtemel bir revolverin patlatılmasını takiben Yunan askerlerinin derhal kışlaya karşı vaziyet alarak kışla cephelerini hiç ara vermeksizin ve kesintisiz ateşe tuttuğunu belirtmiştir ${ }^{37}$.

36 Sabah, “İzmir Nasıl İşgal Edildi”, 26 Mayıs 1919.

37 İkdam, 2 Haziran 1919. 
Bütün bunların ötesinde uzun yıllar İzmir'in işgali, her y1ldönümünde tekrar hatırlanmıştır. Nitekim işgal sırasında hayatını kaybedenler anılmış, kargaşanın nasıl başladığı üzerinde durulmuş öte yandan Hasan Tahsin'in olaylar sırasında hayatını kaybettiği belirtilse de hiç bir yerde "ilk kurşunu" attığına değinilmemiştir. Örnek vermek gerekirse; Yunan işgaline karşı direnişin önemli isimlerinden olan ve kargaşa esnasında İzmir'de bulunan, Yunan işgali altında beş gün İzmir'de gizlendikten sonra İstanbul'a kaçmayı başaran Mustafa Necati, Vasıf Çınar ile birlikte daha sonra Balıkesir'de "İzmir'e Doğru” gazetesini çıkarır. İlk sayısı 16 Kasım 1919'da çıkan ve 27 Haziran 1920'ye kadar 74 sayı çıkabilen gazetede "İzmir'e Doğru” başlığı altında gazetenin bu ismi kullanmasından hareketle İzmir'in işgali ele alınır. Bunun yanında 16 Mayıs 1920 tarihli sayıda ise: "Dün 15 Mayls tarih-i meşumu; bütün Türklügün en şeni ve zehirli hançerler altında mukaddesat-l diniye ve mevcudiyetinin payimal edildiğini görmek ve müttezih olduğ kara bir gündü’” ifadeleri ile başlayan yazı işgal gününü anlatmaktadır ${ }^{38}$. Sadece bu yazı da değil gazetenin bundan sonraki sayılarında da İzmir'in işgali defalarca konu edilmesine rağmen hiçbir sayıda Hasan Tahsin ile ilgili bir ifade yer almamaktadır.

15 Mayıs 1920 günü yayınlanan İkdam gazetesi "İzmir İşgal-i Facias1nın Sene-i Devriyesi" başlığı altında şehit olan isimler arasında "Hukuk-ı Beşer sahibi Hasan Tahsin Recep" Bey'in de ismi sayılmış ve ardında da " $B u$ şehitleri millet kalbinde sakliyor" ifadeleri kullanılmıştı³9. Bir y1l sonra 15 Mayıs 1921 tarihinde İleri gazetesinde ise "Kara Bir Günün Sene-yi Devriyesi: İzmir'in İşgali” başlığını kullanılarak, Süleyman Fethi Bey, Hasan Tahsin ve 17. Kolordu Sihhiye Reisi Kaymakam Şükrü Bey'in resimlerinin altında “İzmir'i Yunan istilasına karşı ilk müdafaa eden ve ilk şehit olan üç kahraman..." ifadeleri yer almıştır ${ }^{40}$.

İzmir işgalinin yıldönümünde yayınlanan yazılar arasında en dikkat çekici olanlardan biri de İleri gazetesinde "Bir Zatın Naklettiği Hatıraları" olmuştur. Her ne kadar "Bir Zat"ın kimliği açılanmasa da, son derece ayrıntılı bilgiler içeren ve daha sonraki yıllarda da tarihi bir vesika olarak tekrar yayınlanan bu "hatırat" ilk çatışma anı ile ilgili önemli sayılabilecek bilgiler vermektedir. Hatta daha önce hiç bir gazetede yer almayan ayrıntılar bu hatıratta yer

38 H. (Hüseyin) Vasıf, “15 Mayıs”, İzmir’e Doğru, 16 Mayıs 1920.

39 İkdam, 15 May1s 1920.

40 İleri, 15 May1s 1921. 
almıştır. Tek bir silah sesi değil aynı anda iki silah sesinin işitildiğini vurgulayan "zat", saldırının ise silahlı yerli Rumlar tarafından gerçekleştirildiğini iddia etmektedir. Aktarılanlara göre; söylentilerin artması üzerine 14 Mayıs günü ileri gelenlerinden bir heyet Mektebi Sultaniye'de toplanıp Vali İzzet Bey’e gitmiş, Vali ise cevap olarak memleketlere müracaat ettiğini katiyen ateşkesin 7. maddesinin tatbikinden başka bir şey olmadığını, halka telaş ve heyecan verilmemesini ifade etmiştir. Aktarılanlara göre; Metropolit işgalden bir gün evvel, şehrin Yunan askerleri tarafından işgal edileceği resmen bildirilmemiş iken, metropolithane bahçesine celp edilen Rum ahaliye ertesi gün şehrin Yunan askeri tarafından alınacağını bu saatten itibaren İzmir'de Yunan kanunun cari olacağını heyecanlı bir nutukla ilan etmiş ve bunun üzerine de Müslümanlar Yunan işgaline gireceklerini katiyen anlamışlardır ki bu felaket bütün Müslüman İzmirlileri derinden vurmuştur. Bunun üzerine Müslüman ahali Yahudi mezarlığına akın ederek geç vakitlere kadar içtimaalar gerçekleştirmiştir. "Hatıraları nakledilen zat" 15 Mayıs günü sabah sekiz buçuk vapuru ile Karşıyaka'dan İzmir'e gelmek için vapura biner, vapur faciayı seyre giden Rumlar ile doludur:

"Bu elim manzarayl görmemek için arkadaşımla birlikte hükümet binası tarafina gittik... Saat on buçukta Kemeraltı civarına Rumlardan bir akın başladı. Yerli Rumların belki hiç uğramadıkları Kemeraltı'na akınları bir hadise çıkarmaları ihtimalini artık gözle görünür bir hale getirmişti. Zavallı eli bağlı Müslümanlar hem şu feci manzarayl görmemek hem de bir hadisenin vuku ihtimaline karşı birer ikişer evlerine dă̆llmak üzere iken kışla meydanına doğru 25 kişilik bir müfreze-i askeriyenin gelmekte olduğu görüldü. Hükümet konă̆ının deniz ve parka nazır merdivenlerinde duruyorduk. Yunan askerlerinin önünde bir sivil büyük bir Yunan bayrağı taşıyor, binlerce Rum 'Zito' sadalarıyla kışla kapısı hizasına doğru yürüyorlardı. Kışla kapısında Türk askerlerimiz nöbet bekliyorlardı... Askeri kıraathanesi köşesini dönerek polis idaresi cihetine doğru yollanmıştı. Biz bunların nereye gittiğini görebilmek için hükümet konă̆l avlusundaki merdivenlere geçtik. Oradan hapishane-yi umumiye doğru caddeyi seyir ediyorduk, bir iki dakika geçmemişti ki kalabalık arasında iki silah patladı. Hükümet binası ve kışla civarına gelen Yunan kıtaatının önünde ve etrafinda silahlı Rum ahali gidiyorlar idi. İlk silah göğ̈̈sleri çapraz fişekli yerli ahaliden birisi tarafından atılmış ve evvelce takarrür eden (kararlaştırllmış) hadise bu suretle başlamıştır... Ortalıkta müthiş bir karışıklık vardı. Bir an geldi ki müfrezeyi askeriyenin geri dönerek gayr-ı muntazam bir halde geldikleri tarafa doğru seri adımlarla kaçtığını gören kaçacak 
yer ararken İslamlarda emin bir yerdir diye hükümet konağı kapısindan içeriye doğru akın halinde kaçmaya başladılar... Herkes şaş̧ıın bir halde oraya buraya koşuyordu" "4l.

İşgal sırasında İzmir'de öğretmen olarak görev yapan Ahmet Talat Onay olayların yakın tanığı olmuştur. Öğretmenlik görevinin yanı sıra Duygu ve Anadolu gazetelerinin başyazarlığını da icra etmektedir. İşgal günü Reddi İlhak hareketine katkıda bulunduğu gerekçesiyle Divanı Harbe verilir. Ayr1ca Yunanlılar tarafindan başına 20.000 drahmi ödül konulur, bunun üzerine Kastamonu'ya dönen Ahmet Talat Onay Açıksöz gazetesinde İzmir'in işgali sırasında yaşananları dokuz bölüm halinde yayınlar. İlk bölüm 23 Mayıs 1920 tarihinde yayınlanır. Yazı dizisi işgalden önceki döneme 1şık tutar. Özellikle Nurettin Paşa'nın valiliği, İzmir basını, İzzet Bey'in valiliği, Müdafaa-i Hukuk-1 Osmaniye Cemiyeti, işgalden önce Türk Ocă̆ı'nda ve Mekteb-i Sultani'de yapılan toplantılar, Maşatlık mitingi gibi mevzularda önemli ayrıntılar verilir. Onay'ın aktardığına göre işgalden bir gece önce bir grup Nadir Paşa'ya giderek silah ve cephane ister, Nadir Paşa Harbiye Nezaretinden hiç bir emir almadığını, silah veremeyeceğini, silahlı kimi görürse derdest ve divan-1 harbe tevdi edeceğini kat'i bir lisanla bildirir. Bunun üzerine yatsıya doğru yüzü mütecaviz vatansever silah deposunu basarak yeterli miktarda silah ve mühimmat alır, daha sonra bir kısmı İzmir'e bir saat mesafedeki Balçova ve Ilıca tepelerini tutar, diğer kısım ise Ödemiş, Aydın cihetlerindeki efeleri ve halkı mücadeleye davet için hareket eder. Ahmet Talat Onay'a göre; "ilk kurşun" bir Rum'un silahından çıkmış ve "Sarhoş bir Rum'un sevincini ilan eden küçük tabancası bütün İzmir fecayiinin uğursuz başlangıcı" olmuştur.

41 İleri, 15 Mayıs 1922. Öte yandan 28 Ocak 1922 tarihli Vakit gazetesinde, "Millî Mukavemetimizin Canlı Bir Tarihçesi Kazım Paşa ile Mülakat" başlığı altında işgal sırasında İzmir'de bulanan Kazım Özalp ile yapılan söyleşi yayınlanır. Kazım Paşa'nın aktardıklarına göre; Muvaffak Bey'in işgal haberini vermesi üzerine içlerinden İzmir'in gençlerinden Necati, Haydar, Anadolu gazetesinden Reşat, Hüseyin Ragıp, Moralizade Halit'in bulunduğu bir grup idadi mektebinde toplanmıştır. Toplantıda bir heyet seçilmiş ve Valiye gitmiştir. Toplantı sırasında Kazım Paşa ise "Mukavemet edilmelidir, silahı olan, silahını alsın, asker, jandarma ne varsa tepelere çıı muharebe edelim" teklifinde bulunmuştur. 15 Mayıs sabahı ise Kazım Paşa subayların son kararını anlamak için belediye kahvesine gider. Mukavemet için hükümette hiçbir hazırlık olmadığını anlar, bu arada ahali heyecan ve endişe içinde şuraya buraya koşmakta, bazıları da askeri depolardan silah almaktadır. Mahpusların dağıtıldığını ve silahlananlar olduğunu gören Kazım Paşa İzmir'de kalmayı gereksiz ve tehlikeli bulur ardından da eve gider, kardeşi Fethi ise jandarma deposundan silah almaya gitmiştir. Kardeşi Fethi Bey ile Menemen'e gitmeye karar verirler, istasyona giderek trene binerler. Kazım Paşa böylelikle işgalden kısa bir süre önce İzmir'den ayrılmış olur. Vakit, 22 Ocak 1922. 
Rum, Ermeni ve Musevi'den mürekkep bir kafilenin hükümet civarında Beyler Sokağı'ndaki polis emanet deposunu yağma etmesi üzerine Vali İzzet Bey ve Ali Nadir Paşa'nın emri ile silah yağma edenleri tevkif ve te'dibe memur edilen ve kışlanın tramvay caddesine nazır kapısından bir müfreze piyade, bir müfreze süvari Türk askeri çıkmaktadır. Önlerinde büyük Yunan bandırası, etraflarında binlerce Rum bulunan bir tabur Efsun askeri de kışla önünden geçmektedir. Tam da bu esnada sarhoş bir Rum'un sevincini ilan etmek için küçük tabancasını ateşlemesi çatışmanın başlangıcı olmuştur. Diğer yandan Onay'a göre ilk silah patlamasıyla mitralyözlerin işlemesi arasında geçen sürenin yalnız iki dakika olduğu dikkate alınınca bunun tertip olduğu da ortaya çıkmaktadır. Bu konuda isim de veren Onay; "Türklerin imhasına, firarlarına çalışılması" işinin Atina'da kararlaştırıldığını, bu konudaki planı tertip etmek üzere Çürükcüoğlu Nikolaki'nin oğlu John ve bir kaç kişinin işgalden evvel Atina'ya gittiğini, hatta bu plan dairesinde Müslümanların üzerine ateş açan kişilerin bunlar olduğunu söyler ${ }^{42}$.

Diğer yandan işgalden sonra İzmir'de iki aydan fazla gizlenen ve İzmir basınının önemli isimlerinden, Anadolu ve Duygu gazetelerinin sahibi, aynı zamanda İzmir Türk Ocağı idare heyetinde de yer alan Haydar Rüştü (Öktem) Antalya'ya gelir. Burada Antalya Müdafaa-i Hukuk Cemiyeti’nin sağladığı maddi destek ile 19 Aralık 1920 tarihinden itibaren gazetesini "Antalya'da Anadolu" adıyla yayınlamaya başlar. Aynı yıl içinde Anadolu matbaasında Antalya Müdafaa-i Hukuk Cemiyeti tarafindan bastırılan "Izmir'de Neler Oldu?" adlı on sayfalık bir kitapçık gazete eki olarak ücretsiz dağıtılır. İsimsiz basılan kitapçığın kapağında: "Her Müslüman okusun, İzmir'e giren Yunanlıların yaptığı, zulümleri gören bir zat tarafindan yazılan şu ibretli yazıları okuyup uyanalım" ifadeleri yer alır. İlave olarak: "Okuyan okumayana versin ve herkes bunu birbirine anlatsın" uyarısı da yer almaktadır. Muhammed Güçlü ${ }^{43}$ ve Erdoğan Sorguç'a ${ }^{44}$ göre Haydar Rüştü'nün kaleme aldığ 1 bu kitapçıta daha çok işgalin ilk günü üzerinde durulur, ancak ne Hasan Tahsin'den ne de "ilk kurşundan" söz edilmez. Kitapçıkta aktarılanlara göre;

42 Ahmet Talat Onay, Millî Mücadele Yazıları, Hazırlayan Cemal Kurnaz-Şefika Kurnaz, MEB Yayınları, 2. Baskı, İstanbul, 2004, s. 57.

43 Güçlü, metni Haydar Rüştü'nün yazdığına dair bazı çekinceleri de dile getirir. Muhammet Güçlü, 'İzmir'in İşgaline Tanık Bir Zatın Kaleminde: 'İzmir'de Neler Oldu' 1336/1920' Kitapçı̆̆1 Üzerine”, Dokuz Eylül Üniversitesi Atatürk İlkeleri ve İnkılap Tarihi Enstitüsü Çağdaş Türkiye Tarihi Araştırmaları Dergisi, X/22, (2011/Bahar, s. 65-75.

44 Erdoğan Sorguç, "İlk Kurşun"un Seyir Defteri 1918-2014, Dörtyol Belediyesi Kültür Yayınlar1, 3. Bask1, Hatay, Eylül 2016, s. 30. 
15 Mayıs günü Yunan orduları Punta ve Pasaport mevkilerinden Kordon'a ayak basınca sekiz on kola ayrılmış, ortada hiçbir şey yok iken hemen askerler süngülerini takmış, zabitler tabancalarını ele almış ve evvelce Rumların hazırladıkları haritaları alarak, Rum izci çocuklarından ve papazlarından birer ikişer önlerine katarak şehrin dört tarafına birden ilerlemeye başlamışlardır. Kordonboyu papaz, kadın, çocuk, erkek Rumlarla dolmuş, yüzbinler Yunan Bayrağı eşliğinde "Yaşasın Yunanlılar, gebersin Müslümanlar, intikam alını kahramanlar" diye bağırmaktadırlar. "Ve işte o ara bütün manasıyla kızıl ve kanlı kıyametler başladı. Yunan askerleri bulundukları yerlerden ileriye doğru yürümeğe başlayınca Kordon üzerinde işine gücüne giden Müslümanların evvela fesleri alınarak parçaland ve "kaldır ellerini kerata" nameleriyle beraber dipçikler bigünah İslamların kafalarına ve bellerine inmeğe başladı. Bir kol asker Gümrük'e doğru ilerliyor ve her attığ adım başında dünyanın en kaba küfürlerini savurarak dipçik ve süngü ile Müslümanları öldürüyor, diğer bir kol da İskele üzerinde yı̆̆ılan ahali arasına girerek aynı işi yapıyor$d u$. Şimdi Kordon üzeri bir kasaphaneye dönmüss idi”.

Devamında yazar, Ahz-1 Asker Heyeti Reisi Süleyman Fethi Bey'in baş1na gelenleri ayrıntılı bir şekilde aktarır. Kışlada Kur'an-1 Kerim okurken, Yunanlıların hücumuna maruz kalmış, elinden Kur'an-1 Kerim'i alıp çiğnemeye çalışan bir Yunan zabitine vurduğu bir tokattan dolayı ilk süngü yarasını almış, Yunan zabitlerinin emirlerine uymayı reddeden Süleyman Fethi Bey arda arda süngülenmiştir. Yunan zabitleri yaralı halde Süleyman Fethi Bey'i kışladan çıkartıp Kordon'a doğru sevk etmeye çalışır, sevk esnasında ise dipçik ve süngü ile saldırmaya devam ederler. Ancak "Amerikalı ecnebiler" araya girerek, Süleyman Fethi Bey’i bir arabaya koymuş ve yaralı şekilde hastaneye götürmüşlerdir. Yaralı olarak kaldırıldığı hastane de hayatını kaybetmiştir ${ }^{45}$.

Bütün bu haberlerin yanında, "Hasan Tahsin'in 15 Mayıs 1919 günü hayatını kaybedenler" arasında sayılmasının ötesine geçen bir haber, Anadolu'da Yeni Gün gazetesinde yer almıştır. 15 Mayıs 1922 tarihli nüshasını İzmir'in işgaline ayıran gazete Hasan Tahsin'e ait bir fotoğrafi, altına “İzmir' in şehitleri arasında aziz bir meslektaş" ifadesiyle ilk sayfasından yayınlar. Devamında ise Hasan Tahsin'in Yunan askerleri üzerine bomba attığı söylenir: "Kltalin dehşeti esnasinda Yeni Şark gazetesi sahibi cesur Tahsin Recep Bey kendisine savlet eden dört efsunu bomba ile berhava etmiş ve onları cehenneme, kendini

45 Muhammet Güçlü, a.g.m., s. 72. 
nezd-i mevlaya atmıştı"'46. Ancak haberde bu durumun, işgal günü olayları başlatan "ilk atış" olduğuna dair herhangi vurgu olmadığı gibi daha da ötesi olayları başlatan başka bir silah sesinden bahsedilir: "Saat 10'a doğru bir Yunan kafilesi Karantina iskelesinden karaya çıkt. Bu sırada bir efsun müfrezesi arkasında binlerce Rum olduğu halde kışla önüne geldi. Müfrezenin önünde elinde Yunan bandrası olan bir Rum vardı. Bu müfreze kuşlanın önünden Göztepe'ye tramvay caddesine doğru geçti, onu bir müfreze daha takip etti. Tam bu esnada katillerin teheyyücü artmıştı. Bir silah sesi ortalığı hercümerç etti..." ${ }^{\prime 7}$.

\section{IV. İngiliz, İtalyan ve Yunan Belgelerinde “illk Kurşun” ve Hasan Tahsin}

İzmir'in işgalinin ilk günü yaşanan hadiseler ve işgalin İzmir merkezi ile sınırlı kalmayıp kısa sürede genişlemesi dünya kamuoyunun dikkatini çekmiştir. Venizelos bir yandan İtalyanları suçlamakta diğer yandan da işgal bölgesindeki Yunan askeri otoritelerin kendisine eksik veya yanlış bilgi verdiklerini ileri sürmekteydi. Yaşananlar kısa sürede İngiliz Lordlar Kamarasının da gündemine gelir, İngiltere'nin Müslüman dünyasındaki imajını olumsuz etkileyebileceği endişesiyle olaylar kürsüde sert bir dille eleştirilirken, Yunanlılar sorumlu tutulmuştur. Yükselen tepkiler üzerine Yunan başbakanı Venizelos, üzerindeki baskıyı azaltmak için İngiliz yetkililerin başında olduğu bir araştırma heyetinin konu ile ilgilenmek üzere görevlendirmesini istedi ${ }^{48}$. Bunun üzerine Yüksek Konsey 18 Temmuz 1919 tarihinde yapmış olduğu toplantıda İngiltere, Fransa, İtalya ve Amerika delegelerinden teşkil edilecek komisyonun kurulması ve bu komisyonun amacinın 15 Mayıs 1919 tarihinde başlayan Yunan işgalinin ilk günü İzmir'de meydana gelen olayların araştırılması olarak ilan etti. Amerika adına Yüksek Komiser Amiral Mark Lambert Bristol, Fransa adına General Gedrges Hippoltyte Bunoust, İngiltere adına General Robert Hare, İtalya adına General Alfredo DAll'olio komisyona üye olarak görevlendirildi. Komisyona Yunanistan'ın üye teminin de bulunup bulunmayacağı tartışma konularından biri oldu, Yunan temsilcinin komisyonda yer almasına İtalya şiddetle karşı çıktı. Yunan temsilcinin komisyon işlerine

46 Anadolu'da Yeni Gün, 15 Mayıs 1922.

47 Anadolu'da Yeni Gün, 19 Mayss 1922.

48 Michael Llewellyn Smith İzmir'e Müttefikler arası bir soruşturma kurulunun gönderilmesini önerenin Fransız Başbakanı Clemenceau olduğunu söylemiştir. Bkz. Michael Llewellyn Smith, Anadolu Üzerindeki Göz, Hürriyet Yayınları, İstanbul, Şubat 1978, s 124. 
karıştırılmasının tarafsızlığa gölge düşüreceğini öne süren İtalyanlar, bu durumda Türklerin atayacağı bir temsilcinin de çalışmaları takip etmesine izin verilmesi gerektiğini öne sürdü. Sonuçta belli şartlar dahilinde Yunan temsilcinin atanması hususunda anlaşıldı. Yunan temsilci Albay Mazarakis toplantılara katılamayacak, bunun yanında herhangi bir oy ve onay yetkisi de olmayacaktı. Karş11ık olarak Sadrazam Damat Ferit Paşa bir süre sonra komisyona müracaat ederek Türk temsilcinin atanması talebinde bulundu. Venizelos'un karşı çıkmasına rağmen özellikle İtalya'nın desteğiyle Türk temsilci olarak ise Yarbay Kadri atand1.

Bu şartlarda ilk olarak 12 Ağustos'ta İstanbul'da toplanan Komisyon ardından İzmir'deki ilk toplantısını 23 Ağustos'ta Mektebi Sultani'de yaptı. İzmir'de başta İngiliz, Fransız ve İtalyan olmak üzere içlerinde subayların da bulunduğu birçok yabancı olaylarla ilgili ifade verdi. Bunların yanında Tükler ve Rumlardan da bir çok şahit ifadeye çağrıldı. Vali İzzet Bey de, Komisyona bir rapor sunarak; meydana gelen olayları delilleriyle teferruatlı bir şekilde anlatmış; İzmir'in işgali günü hükümet konağının ne surette yağmalandığından, bizzat kendi masasının kilitlerinin nasıl kırıldığından, evrakının karıştıııldığından, hanesi ve ailesinin nasıl kurşun yağmuruna tutulduğundan bahsetmiştir. İzmir'deki çalışmaları 5 Eylül'de yaptığı son toplantıyla bitiren komisyon 6-12 Eylül tarihlerinde Aydın'a geçerek çalışmalarına devam eder. Daha sonra Ödemiş, Nazilli, Menemen, Ayvalık ve Manisa'ya da geçen Komisyon buralarda yaşayan Rum ve Türklerin ifadesine başvurur. İfadesine başvurulanlar arasında Çine'de Yörük Ali Efe de yer alır. Bütün bunların sonucunda Yüksek Konseye sunulmak üzere bir rapor hazırlanır. 175 tanığın ifadesine başvuran Komisyonun raporunda; işgal sırasında Türk idareciler tarafından hiçbir karş1 bir eylemde bulunulmadığı antlaşmalara uygun şekilde Türk askerlerinin kışlalarda kaldığı ve silahlarının toplatıldığı raporlarda altı çizilen noktalardan biri olurken diğer yandan Türk makamlarının bu çabalarına rağmen Yunan yetkililerin güvenliğin sağlanması için gerekli tedbirleri almadıkları özellikle belirtilmiştir. Bunun yanında Yunan askeri ve sivil otoritelerin durumu sakinleştirmek ve kalabalıkları teskin etmek adına hiçbir girişimde bulunmadığı, ayrıca gayrimüslim halkın Türkleri kışkırtmak için tahrik edici davranışlara giriştikleri tespiti yapılmıştır. Yunan yetkililerin işgal planlarına tam olarak uymadığının altı çizilirken, İtilaf Devletlerine danışmadan işgal planlarına değiştiren Yunan askeri otoriteleri olaylardan doğrudan sorumlu tutulmuştur. 
Yunan yetkililer ifadelerinde kışla önünden geçerken, kışla penceresinden, kendi üzerlerine bir el silah atıldığ ni öne sürerken, buna karşıllk Kadri Bey ifadesinde İzmir'in işgali sırasında meydana gelen olayların başlangıç ve sebebi sayılan ilk silahın atılışı üzerinde ayrıntılı olarak durmuş, yaşananlardan Yunanlıları sorumlu tutmuştur: “... ne kuşlanın penceresinden, ne de başka bir yerden Yunan askeri üzerine hiç bir silah atılmamıştır... Yunanlıların o vahşiyane hareketi, o gün tesadüfen hasıl olmuş bir hadise değil, belki uzun bir hazırlı̆̆ın tatbikat-ı hunharânesinden ibaret idi. Ve o sebeple de Müslümanların sükûn-ı mutlakı karşısında kati bahanesini bizzat kendilerince ihdasa mecbur kalinca kendilerinden bir Rum'a bir el tabanca attırdıkları tahakkuk etmiş idi"49.

Raporun çalışma konumuzla ilgili olan kısmında ise işgalin ilk günü meydana gelen olaylara değinilirken açılan ilk ateşten bahsedilmekte ve failin katiyen tespit edilemeyeceği belirtilmektedir. Buna karşıllk ilk ateş sonrasında Yunan askerleri tarafından yaylım ateşi açıldığı üzerinde durulmaktadır. Bu konuda kışladan ateş açılıp açılmadığının belirlenememesine karşın kışlanın tam karşısında yer alan duvarlarda mermi izine rastlanmamasının ateş açılmadı̆̆ı olasılığını yükselttiği de belirtilmiştir ${ }^{50}$.

İşgalin ilk günü meydana gelen olaylar İngiliz yetkilerin raporlarında ve bölgede yaşayan İngilizlerin mektuplarında ayrıntılı olarak yer almaktadır. Söz konusu belgeler içinde hem işgal günü ile ilgili ayrıntılı bilgiler içermesi hem de Hasan Tahsin'den bahsediyor olması bakımından Ian Smith'in kaleme aldığı metin dikkat çekmektedir. İşgalden önce İzmir'e İngiliz Hükümeti tarafindan Bölge Kontrol Subayı olarak gönderilen Ian Smith'in kaleme aldı̆̆ı ve 24 Mayıs 1919 tarihli Foreign Office 371/4231, 4114-"I" say1lı rapor İstanbul'daki İngiliz İstihbarat Servisi'ne hitaben yazılmıştır. Ian Smith aynı zamanda 14 Mayıs 1919 sabahı ve akşamı James Morgan ile birlikte İzzet Bey ve Nadir Paşa'yla görüşüp, bu konuda Amiral Calthorpe'a notlar ileten yarbaydır. 13 Mayıs'tan 17 Mayıs'a kadar ki gelişmeleri aktaran rapor Amiral Calthorpe tarafından 15 Haziran 1919'da İstanbul'daki Yüksek Komiserliğe havale edilmiştir ${ }^{51}$.

49 Mustafa Turan, “İstiklal Harbinde 'Müttefikler Arası Tahkik Heyeti’ Çalışmaları, Raporu ve Tahkikat Neticesi”, Ankara üniversitesi Türk İnkılap Tarihi Enstitüsü Atatürk Yolu Dergisi, S 8, 1991, s. 704.

50 Bkz. İsmail Ediz, a.g.e., s. 196-208.

51 Buğra İnal, "Bir İngiliz Subayının Gözünden İzmir'in İşgali ve Yaşananlar”, Büyük Taarruzun 90. Yıldönümünde Uluslararası Millî Mücadele ve Zafer Yolu Sempozyumu, Atatürk Araştırma Merkezi Yayınları, C II, Ankara, 2014, s. 1212. 
Ian Smith raporun başında hükümet yetkilileri ile yaptığı görüşmeleri ayrıntılı olarak aktarır. 14 Mayıs günü Yunan ordusu tarafından şehrin işgal edileceğini bildirdiklerinde, bu durumun başta Vali olmak üzere tüm askeri yetkililerde ağır bir şok etkisi yarattığının altını çizer. Görüşmede tüm Türk birliklerinin, Yunan birlikleriyle karşılaşma ihtimaline karşı kışlalarında kalmaları gerektiği, askeri ve sivil yetkililerin de Yunan Kuvvetleri Komutanı'ndan emir gelmedikçe ofislerinden çıkmamaları gerektiği vurgulanır. Hatta hükümet konağından ayrılırken etrafları 20-30 kadar Türk muteberleri temsil eden delege, din adamı ve tüccar tarafından sarılır. Bu kişiler tarafından İzmir, şehirde azınlık olan Yunan uyruğun yönetime bırakılırsa bölgede barış ve huzurun hiç bir zaman sağlanamayacağı ifade edilir.

Smith'in raporunda ilk çatışmanın başladığı nokta genel anlatıdan farklı olarak rıhtım olarak gösterilir:

"Konak da çatışma başladığında rıhtımdan da silahlar ateşlenmeye başladı. Bu genel bir Türk avinın başladığına delaletti. Yunanlılar ilk ateşin rıhtıma yanaşmış olan bir Türk gambotundan yapıldığın ileri sürdüler. Bu iddia yetkililerin gösterdiği kanıtlar ve gambotun yanına demirlemiş olan Adventure'daki Ingiliz Kraliyet donanması çallşanlarinin ifadeleri çerçevesinde klsa sürede yalanlandl. Ardından bu bölgede ikamet eden bir Ingiliz Bay Forbes yaşananlara ofisinden şahit olduğunu söyleyerek; silahlı çatışmanın dışarı doğru koşan bir sivilin, rıhtımın yakınındaki motorlu sandalda bulunan ve çıkarmaya karşı hiçbir tepki vermeyen birkaç Türk denizcisine ateş etmesiyle başladı̆ğn ifade etmiştir. Illk atışın yapılmasının ardından rihtımdaki kalabalık ve Yunan askerleri rıhtım civarında üzerinde Türkçe yazılar ya da Türkçe isimler bulunan tüm evlere ateş açtılar. Askerler ve toplanan kalabalık daha sonra tüm evlere zorla girdi ve buldukları Türkleri dışarı sürükleyip eşyaların yağmaladılar. Kısa süre sonra Konak'ta toplanan esir kafilesi 1.2 kilometre uzaktaki Yunanl nakliye gemisi Patris'e bindirilmek üzere aşăğ, rihtıma doğru götürüldü. Esirlerden oluşan bu gruptaki herkesin başındaki fesler çıkartılmıştı ve bu insanlar elleri havada iken Yunan askerlerinin dipçik ve süngü darbeleriyle acele ettirilerek yürütülüyorlar ve 'zito' diye bağırmaya zorlaniyorlardı".

$\mathrm{Bu}$ arada İngiliz yetkililer mevcut huzursuzlukları acilen sonlandırmas1 ve tutuklu bulunan sivil Türk yetkililerin de biran önce serbest birakilarak göreve iade edilmesi hususunda, Yunan komutan Zafiriyu'yu ziyarete giderek 
kendisi ile yapılan ve halen yapılmakta olan hatalara yönelik şiddetli bir konuşma gerçekleştirirler. Yaşanan kargaşanın Yunan gazetelerinde "Türklerin organize bir şekilde karşı koymaları ve kışladan, Yunan askerlerine saldırmaları" sonucu ortaya çıktığı şeklinde yansıtılmasına karşılık Smith raporuna şu ifadeleri de ekler:

"Şundan eminim ki Yunan Birlikleri'nin karaya çıkmalarına karşı koymak için yapllan organize bir hazırlık yoktu ve Türk sivil ve askeri yetkililer kendi askerlerine klşlalarından dışarıya çıkmamaları ve onlardan emir beklemeleri şeklinde talimat vermişti. Bu tür emirler kesinlikle Yunan komutanından gelmemiş̧i. Türk birlikleri kışlalarında kaldılar ve Yunan ordusu ile temasa geçmek için de hiç firsat aramadılar. Yunanlılar ise Yüksek Komiserin düzeni sağlama yönündeki tüm düşüncelerinin aksine geniş ve gösterişli sivil kalaballğın eşliğinde Türk kışlalarına doğru yürüyüşe geçtiler ve çarpışma kaçınılmaz oldu".

Sonuç olarak asıl önemli olan ve Smith'in raporunu diğer resmi belgelerden ayıran Hasan Tahsin'in ölümünden bahsetmesidir. İzmir Müdafaa-i Hukuk-1 Osmaniye Cemiyeti tarafindan Osmanlı sulh murahhaslarından Tevfik Paşa'ya takdim edilen muhtırada belirtildiği gibi, Hasan Tahsin'in evinde öldürüldüğünü öne sürülmüştür: "Bir sivilin bir evde Türk bulunduğunu ihbar etmesi birkaç askerin toplanarak o eve girmesi için yeterli bir sebepti. Tabii bazı evlerde direnişle karşılaştıkları da oluyordu. Bir örnek vermek gerekirse 1913 yllinda Bulgaristan'da Bay Buxton'a suikast girişiminde bulunan Tahsin Bey Yunan müfrezesi ile girdiği çatışmada süngülenerek öldürülmüştü’,52.

Diğer yandan işgal sırasında İngiltere adına en faal isimlerden biri İngiliz Yüksek Komiserliği’nin İzmir Konsolosu James Morgan'dır. 14 Mayıs sabahı Mondros Ateşkesinin 7. Maddesine dayanarak müstahkem mevkilerin işgaline dair kararı içeren mektubu Vali ve Kolordu Komutanına ulaştıran kişidir. Aynı kişi 14 Mayıs akşamı ise bu sefer Ian Smith ile birlikte şehrin ertesi sabah Yunan birlikleri tarafından işgal edileceğini İzzet Bey ile Nadir Paşaya bildirmiş ve kargaşa çıkmaması için gerekli önlemleri almaları konusunda uyarmıştır. James Morgan 20 Mayıs tarihli raporunda; yaşanan kargaşadan Yunan Birliklerinin Komutanı Zafiriyu'yu sorumlu görmekte ve Yunan Birlikleri'nin kışladan uzak tutulması konusunda subaylara gerekli emirleri vermediği ve aynı zamanda Türk yetkilileri konuyla ilgili olarak bilgilendirmediği için suçlamaktadır. Nitekim Morgan'ın raporunda işgal günü yaşanan-

52 Raporun tercümesi için Bkz. Buğra İnal, a.g..e, s. 1213-1222. 
lardan Yunanlılar sorumlu tutulmaktadır: "İzmir 19 Mayıs günü Yunanlılar tarafindan işgal edildi işgal son derece disiplinsiz şekilde gerçekleştirildi. Birçok yerde çatışmalar meydana geldi Hristiyanlar tarafindan yapılan kışkırtmalar neticesinde birçok Türk gereksiz yere tutuklandl... Rum ayaktakımı etraftaki köylere saldırmakta, Rumların Türkleri yağmalama ve avlama eylemleri devam etmektedir. 300 Türk 100 Hristiyan kayıptır" ${ }^{53}$. Ayrıca Morgan, Türk tutukluların bir Yunan gemisine götürüldügünü, geminin doğu tarafına bağlanmış mavnanın hapishane olarak kullanıldığını, burada üzerleri aranan mahkumların bütün değerli eşyalarının alındığını, şehirde çatışmaların yer yer devam ettiğini, hastanelerin ölü ve yaralı Türklerle dolup taştığını ve Türk yaralıların tedavisi için hiçbir şey yapılmadığını, hatta yiyecek yemek dahi verilmediğini belirtmiştir ${ }^{54}$.

Kışladan ateş açılmadığını not eden isimlerden biri de Charlton Whittall'dir. İzmir'in önde gelen Levantenlerinden biri olan Whittall, olaylar sırasında hükümet meydanındaki kışlanın ön kapısına bakan şirket ofisinin balkonunda idi. 20 Mayıs tarihli mektubunda yaşanan kargaşayı şu sözlerle aktarır: "Rıhtım tarafindan meydana doğru ilerleyen Yunan askerler barakaların önünden geçtiği esnada birkaç el silah duyuldu. Bununla birlikte Yunan askerleri geriye doğru koşmaya başladı ă̆açların arkasında siper olan Yunan askerleri gördükleri her şeyi kurşun yağmuruna tuttular. Tahminimce ilk silah atışı kahvehaneden geldi ve kesinlikle kışlalardan gelmedi. Bunun en büyük ispatı kışlaların tam karşısında yer alan bulunduğum şirketin ofis binasının önünde hiçbir kurşun bulunmamasıdır" ${ }^{25}$.

Diğer yandan İtalyan istihbaratın İzmir ayağının son derece "iyi çalıştığı" ve İzmir konusunda "aşırı hassasiyete" sahip olduğu gönderilen rapor sayısından ve içeriğinden anlaşılmaktadır. İtalyan yetkililer tarafından hazırlanan raporlarda "ilk kurşun" meselesi de konu edilir. Ancak ilk ateşin kim tarafından atıldığı konusunda herhangi bir bilgi yer almaz. İtalyan belgelerinde İzmir’e

53 F.O. 608/104/4, No: 14241, Rapor No: 21. Aktaran İsmail Ediz, Diplomasi ve Savaş, s. 158.

54 Öte yandan İngiltere'nin Atina Büyükelçisi Granville, Yunan askerlerinin yanlışlıkla Türk bölgesine girmiş olduğunu bu esnada Türk askerlerinin Yunan birliklerine ateş açtığını ve bu sebeple çatışma çıktığını belirtir. Granville'nin iddiasına göre kalabalığın içinden bazıları Yunan askerlerine nereden ateş açıldığını göstermiş ve bunun üzerine evlere ateş açılmış, baskın yapılmıştır. Ayrıca kargaşada İtalyan parmağının olduğuna dair önemli delillerin varlığından da söz edilmektedir F.O. 608/104/4, No:11298, Telgraf No: 281. Aktaran Ediz, a.g.e., s. 159.

55 F.O. 608/104/4, No: 14241. Aktaran Ediz, a.g.e., s. 160. 
çıkan Yunan birliklerinin yerli Rumların alkışları arasında ve müzik eşliğinde Konak'a doğru ilerlerken atılan kurşundan sonra katliama başladıkları ve rastgele ateş sonucu Yunan askerlerinin 400'den fazla Türkü öldürdükleri ve 300 kadarını da yaraladıkları, yerli Rumların ise Yunan askerleri ile işbirliği yaparak Türklere ait dükkanları, İtalyan ve Fransızlara ait mağazaları yağmaladıkları belirtilmektedir ${ }^{56}$. 15 Mayıs günü yaşananlarla ilgili benzer içeriğe sahip bir diğer rapor da İzmir İtalyan Delegasyonundan, İstanbul Yüksek Komiseri Kont Sforza'ya gönderilen metindir. Raporda; sokakta karşılaşılan bütün Müslümanların dövüldüğü ve feslerinin yırtıldığı, kışlada bulunan asker ve subayların tutuklanıp dövüldüğü, çoğunun öldürüldüğü, yanlarındaki değerli eşyaların yağmalandığı, aralarında Nadir Paşa'nın da bulunduğu paşaların dövülerek "Yaşasın Venizelos" demeye zorlandığı, yağmaya Yunan askerinin de katıldığı, hırsızlık ve tahribatın verdiği zararın bir milyon Türk lirası olduğu, işgal sabahı halk adına İtalyan konsolosluğuna gelen Belediye Başkan1, Müftü ve Mevlevi Şeyhinden oluşan heyetin dönüşlerinde Yunanl1lar tarafından tutuklandıkları gibi ayrıntılar yer almaktadır ${ }^{57}$.

İzmir' in işgali sırasında rıhtımdaki İtalyan muhribi Bronzetti'den, Deniz Kuvvetleri Komutanlığı'na gönderilen raporda ise; 15 Mayıs sabahı saat 10'da karaya çımaya başlayan Yunan askerlerinin Kordondan, Konak istikametine doğru ilerlemeye başladıkları, Rumların alkışlarla eşlik ettikleri birliklere önce bir el, ardından da üç dört el daha ateş edildiği, bunun sonucunda karışıklık meydana geldiği belirtilmiştir. Yunan askerlerinin mitralyözle desteklenen ateşe başladıkları, halkın panik içerisinde iç sokaklara doğru koşarken pek çok sivilin denize atladığı, Yunan askerlerinin üç dört yönden Türklerin üzerine ateş açtıkları da ilave edilmiştir ${ }^{58}$. Rıhtımdaki bir diğer İtalyan savaş gemisi Duailio'dan 18 Mayıs 1919 tarihinde gönderilen raporda; Türklerin işgale karşı koymak ve direnmek için hiçbir davranışta bulunmadığı, Yunan askerlerinin alkışlar ve müzik eşliğinde Türk mahallerine doğru ilerlerken ilk kurşunun sıkıldığı söylenmektedir ${ }^{59}$.

Bütün bunların yanında İtalya'nın mütareke döneminde Osmanlı ülkesindeki en önemli temsilcisi olan Kont Sforza yıllar sonra anılarında "ilk kur-

56 Yüzbaşı G. Fauda'dan Başkomutanlığa. Aktaran Mevlüt Çelebi, İtalyan Arşiv Belgelerinde Anadolu'da Yunan Mezalimi (1919-1922), Atatürk Araştırma Merkezi Yay., Ankara, 2000, s. 13.

57 Mevlüt Çelebi, a.g.e., s. 16-17.

58 Mevlüt Çelebi, a.g.e., s. 17-18.

59 Mevlüt Çelebi, a.g.e., s. 19. 
şunu" Yunanlıların attığını ileri sürer. İtalyan muhbirlerin kendisine verdiği bilgiye dayanarak, "ilk kurşunun" olayları hazırlamak için bir Yunanlı veya Rum tahrikçi tarafından atıldığını, hatta "ilk kurşunun" atılması için Atina'dan bilhassa talimat verilmiş veya Yunan ordusu komutanının kolay bir muharebe yapabilmek, kolay bir zafer kazabilmek için böyle bir tedbire başvurmuş olabileceğini ifade eder ${ }^{60}$.

15 Mayıs 1919'da yaşanan kargaşanın faili ve sorumlusu konumunda bulunan Yunan yetkililer; Efsun taburuna hükümet konağı meydanına geldiklerinde, ansızın hükümet dairesinden, kışladan ve civar evlerden ateş açıldığı iddiasındadır. Bir yandan direnişin sorumlusu olarak İttihat ve Terakki unsurları görülmüş diğer yandan ise asıl sorumlu olarak İtalyanlar işaret edilmiştir. Özellikle İtalya'nın denetiminde olan şehir hapishanesinin işgalden bir gece önce boşaltılmasının sorumluluğu İtalyan yetkililere yüklenmiştir. Nitekim Konak Meydanı'nda yaşanan çatışmada hapishaneden kaçan Türklerin etkili olduğu ileri sürülmektedir ${ }^{61}$.

Yunan kaynakları arasında Hasan Tahsin'in isminin geçmesi bakımından Mihail Rodas'ın anıları son derece önemlidir. Mütareke döneminde Yunanistan lehine kamuoyu oluşturmak üzere İzmir'e gelmiş ve işgal boyunca Yunan Matbuat Kaleminde müdür ve sansür memuru olarak çalışmıştır. Yunanistan'a döndükten sonra ise birçok resmî belgeyi içeren anılarını kaleme almıştır. Mihail Rodas anılarında işgalden önce İzmir'in Türk mahallerinde yaşanan gergin bekleyişten ve huzursuzluklardan söz ettikten sonra Hasan Tahsin ile ilgili gözlemlerini aktarır:

"Türk toplumundaki tüm bu hareketlilikler içerisinde Hukuk-ı Beşer'de gazetecilik yapan Kafkas Hasan Tahsin ile tanıştım. Tahsin bir ay önce bana sahip olduğu hümanisttik ilkelerinden ve Türk halkinın yönetimi ile ilgili eleştirilerinden söz etmişsti. Gazetesinde birçok sosyalist makale, hatta Bolşevik fikirlere yakın yazllar yayınlamışt. Hayali bir gün halkların kardeş olarak bir arada yaşamasiydl. Hatta gazetesinde Tahsin, Türkler ve Yunanlların bir an önce işbirliği yapması gerektiğini öne süren bir dizi makale yayınlamaktan çekinmemişti... Onu kizgin kalabalıklar arasinda gördüğ̈̈mde geliş̧meler hakkında fikrini sormuştum. O da hiç tereddüt etmeden bana koşulların zorunlu

60 Hayat Tarih Mecmuası, "Bir İtalyan Politikacısının Kaleminden Kurtuluş Savaşı'mızın Bir Tahlili”, S 12, Aralık 1975, s. 50.

61 Nilüfer Erdem, Yunan Tarihçiliğinin Gözüyle Anadolu Harekatı (1919-1923), Derlem Yay., İstanbul, 2010, s. 168. 
kılması halinde Türk halkının müdafaası için ilk sırada yer alacă̆ını söylemişti. Gerçekten de 15 Mayls akşamı bu Kafkas gazetecinin İzmir'deki askeri karargâh önünde cansız bedeni bulunmuştu" ${ }^{2}$.

Her ne kadar Rodas'ın yukarıdaki ifadelerinde "ilk kurşunu" atanın Hasan Tahsin olduğuna dair bir ima olmamasına rağmen Türkiye'de yayınlanmış eserlerin bazılarında "Hasan Tahsin'in ilk kurşunu atmış" olabileceğinin kanıtı olarak görülmüştür. Ancak Mihail Rodas "Yunanistan Küçük Asya'da, (1918-1922)" başlıklı anılarında "Türk Direnişi” başlı̆̆ı taşıyan bölümde "ilk kurşun" konusunda şunları yazmıştır:

"Birliğin önünde bulunan ilk askerler hapishane yoluna girer girmez, ansizin bir el ateş sesi duyuldu; hemen ardindan ise Yunan askerlerinin üzerine doğru adeta bir ateş yağmuru başladı. (Bu gelişme karşısında) Birliğin başındaki Binbaşı Konstantinos Cavellas, yol ortasinda bulunduğu sirada, Türk askerleri ve bir önceki gece salvverilerek askere alınan mahkumların toplanmış olduğu cezaevinin üst tarafindan ateş açılmasına rağmen, derhal olağanüstü bir soğukkanlılıkla savunma önlemleri alma yoluna gitti. Elimizdeki oldukça güvenilir bilgilere ve izlenimlere göre Türklere saldirt işareti vermek için açılan bu ateş organize bir eylemin sonucuydu. Hedeflenen İzmir'in zaptı sirasinda isyan başlatmak ve düzensizlik yaratmaktı. (Kaldı ki) Hiç bir şüpheye yer birakmayacak bir şekilde belirtilebileceği üzere ilk kurş̧undan çok kisa bir süre önce Türklere ait iskelenin hemen yanında Türk olmayan motorlu bir sandal ve Türk askerlerinin arkasinda, fanatik Türklerin arasında dolaşan çok sayıda şüpheli kişiler görülmüştü."

Mihail Rodas isim vermese de, Türk komitac1ları cesaretlendirenlerin İtalyanlar olduğunu ima eder. Yunan birliklerinin, hükümet binası önünden geçerek Türk mahallesinin içlerine doğru ilerlediği sırada ateş açmaya ve saldırı gerçekleştirmeye kati suretle cüret edemeyeceğini öne sürer ${ }^{63}$.

62 Mihail Rodas, I Ellada Stin Mikran Asia (1918-1922), Tipografeia: Kleisouni, 1950, s. 57.

63 Mihail Rodas, a.g.e., .s 69-70. 


\section{SONUÇ}

İzmir'de Yunan askerlerine karş1 "ilk kurşunun" nerede, ne zaman ve kim veya kimler tarafından atıldığ 1 konusunda farklı görüşler ve ifadeler mevcut olmasına rağmen, Millî Mücadele'nin “Hasan Tahsin'in Yunan askerlerine attığı ilk kurşunla başladığı” tezi 1940'lardan itibaren dile getirilir. Bu konudaki ilk örneklerden biri de Rahmi Apak'ın kaleme aldığg "İstiklal Savaşında Garp Cephesi Nasıl Kuruldu” adlı ederdir. 1942'de ilk baskısı yapılan eser daha sonra yayınlanan birçok çalışmada, "Hasan Tahsin'in ilk kurşunu attığı" iddiasının referansı olarak gösterilecektir. Ancak; Rahmi Apak'ın eserinde Hasan Tahsin ile ilgili iddiayı bir "söylenti" olarak değerlendirip "ilk kurşun" konusunda kendisi için daha "gerçekçi" görünen başka bir olasıllktan bahsetmesi genellikle göz ardı edilmiş, "ilk kurşunla" ilgili metinde aktarılan "yağız delikanlıya" dayalı anlatı yok sayılarak son derece "seçici" bir tavır sergilenmiştir. Hatta "ilk kurşun" konusunda öne sürdüğü iki olasılık birbirleriyle karıştırılacak, zamanla Apak'ın eserinde yer almayan bir "kurgu" da ortaya çıkacaktır.

"Hasan Tahsin ve ilk kurşuna" dayalı anlatının kamuoyuna taşınması Yusuf Ziya Ortaç eliyle olmuştur. Çınaraltı dergisinde Rahmi Apak'in eserini kaynak göstererek; Hasan Tahsin'in, Kordon rihtımına çıkan Yunan Efsun Alayının başındaki mangaya "Revolverle ateş ederek ilk silahı patlatan ve orada vatan için ölen genç bir fedai" olduğu ancak buna karşılık tarihte adının yer almadığından yakınır. Ardından uzun yıllar sürecek olan bir tartışmasının fitilini ateşleyecek şu sözleri ifade eder: "Hani bu kahramanın şehit düştüğü yerde yükselen heykeli?" ${ }^{64}$. Yusuf Ziya Ortaç'ın yazısın1, Cumhuriyet Halk Partisi Genel Sekreterliği “dikkate değer" bulmuş olmalı ki CHP İzmir Vilayet İdare Heyeti Reisliğine gönderdiği 24.09.1942 tarihli resmî yazıda, Hasan Tahsin'in Yunan askerlerine karşı Kordon'da "ilk kurşunu” attı̆̆ını belirttikten sonra Hasan Tahsin ile ilgili İzmir İl Teşkilatı'ndan bilgi talep etmiştir ${ }^{65}$.

1950'lilerden itibaren özellikle de 1960 darbesinden sonra, "Hasan Tahsin'in "ilk kurşunu" atarak Millî Mücadeleyi başlattığı tezi daha sık dile getirilir. "Resimli Tarih Mecmuası", "Tarih Anlatıyor", "Yakın Tarihimiz" gibi dergilerde; Hamza Osman Erkan, Fahri Can, Cemal Kutay, Ertan Ünal gibi isimler makaleleriyle, Ömer Sami Coşar, Samim Kocagöz, Hasan İzzettin

64 Yusuf Ziya Ortaç, “Hasan Tahsin”, Çınaraltı, sayı 50, C. 2, 6 Eylül 1942,

65 Başkanlık Cumhuriyet Arşivi, 490.1.0.0.570.2271.1. 
Dinamo, Şevket Süreyya Aydemir gibi isimler ise eserleriyle bu sürece katkı sunar. Bunların yanında Hasan Tahsin ile ilgili anlatının inşasında; İzmir Gazeteciler Cemiyeti'nin faaliyetleri ve yine bu cemiyetin üyesi olan İzmirli gazeteciler Nurdoğan Taçalan ve Zeynel Kozanoğlu'nun eserleri genel algıyı büyük ölçüde şekillendirir. Bu isimlere Bilge Umar, Türkmen Parlak ve Ümit Sinan Topçuoğlu'nu da eklemek gerekir.

Öte yandan Hasan Tahsin ile ilgili anlatıya sık sık başvurulması Kıbrıs sorunu dolayısıyla Türk-Yunan ilişkilerinden de bağımsız değildir. Nitekim Hasan Tahsin'i "anıtlaştırma” çabalarının ilham kaynağı Atina'nın Nea Smyrni semtine İzmir Metropoliti Hrisostomos'un heykelinin dikilmesi olmuştur. 1972 yılında İzmir Gazeteciler Cemiyeti tarafından Hasan Tahsin adına bir "ilk kurşun" anıtı dikilmesi için bir kampanya başlatılır. Anıt kampanyası kısa sürede ülke çapında topyekûn bir destek bulur. Nitekim 15 Mayıs 1974 günü Hasan Tahsin adına Konak meydanına dikilen "ilk kurşun" anıtı Cumhurbaşkanı Fahri Korutürk tarafından açılır. Sonuç olarak "ilk kurşun" anıt1; bu konudaki farklı anlatıları, görüşleri ve itirazları unutturarak, "Hasan Tahsin'in ilk kurşunu atarak Millî Mücadeleyi başlattığı" tezini, "kesin" ve "keskin" bir tarihsel doğruya dönüştürecektir. 


\section{KAYNAKÇA}

\section{Arşiv Belgeleri}

Başkanlık Cumhuriyet Arşivi 490.1.0.0.570.2271.1.

Başkanlık Osmanlı Arşivi DH.İ.UM. EK, 66/12.

\section{Resmi Yayınlar}

TBMM Zabıt Ceridesi, Devre:1, Cilt 1, İçtima Senesi: 1, Onaltıncı İçtima, (15.5. 1336 Cumartesi), Ankara, TBMM Matbaası, 1959.

TBMM Zabıt Ceridesi, Devre 1, Cilt 11, İçtima Senesi 2, Kırksekizinci İçtima, (9.7.1337), Ankara, TBMM Matbaası, 1958.

TBMM Zabıt Ceridesi, Devre:1, Cilt 1, İçtima Senesi 3, Yüzbirinci İçtima, (13.9.1338), Ankara, TBMM Matbaas1, 1960.

\section{Gazete ve Dergiler}

Ahenk

Anadolu'da Yeni Gün
Çınaraltı
Hayat Tarih Mecmuası
İkdam
İleri
İzmir'e Doğru
Sabah
Tasvir-i Efkar
Vakit

\section{Kitap ve Makaleler}

Altay, Fahrettin, “İzmir Faciasının Muhakemesi”, Belleten, C 23, S 89, Y11 1959.

Bayar, Celal, Ben De Yazdım, C 6, Sabah Kitapları, İstanbul.

Çelebi, Mevlüt, İtalyan Arşiv Belgelerinde Anadolu'da Yunan Mezalimi (1919-1922), Atatürk Araştırma Merkezi Yayınları, Ankara, 2000. 
Ediz, İsmail, Diploması ve Savaş İngiliz Belgelerinde Batı Anadolu'da Yunan İşgali, Atatürk Araştırma Merkezi Yayınları, Ankara, 2015.

Erdem, Nilüfer, Yunan Tarihçiliğinin Gözüyle Anadolu Harekatı (1919-1923), Derlem Yay., İstanbul, 2010.

Güçlü, Muhammet, "İzmir'in İşgaline Tanık Bir Zatın Kaleminde: 'İzmir'de Neler Oldu' 1336/1920' Kitapçı̆̆ı Üzerine”, Dokuz Eylül Üniversitesi Atatürk İlkeleri ve İnkılap Tarihi Enstitüsü Çağdaş Türkiye Tarihi Araştırmaları Dergisi, X/22, Bahar/2011.

İnal, Buğra, "Bir İngiliz Subayının Gözünden İzmir'in İşgali ve Yaşananlar”, Büyük Taarruzun 90. Yıldönümünde Uluslararası Millî Mücadele ve Zafer Yolu Sempozyumu, Atatürk Araştırma Merkezi Yayınları, C II, Ankara, 2014.

İzmir Fecayii, “1 İzmir'in Suret-i İşgali, Harbiye Nezareti ve Umum Jandarma Kumandanlığına Gelen Raporlar ve sair Vesikalar", b.y., t.y.

İzmir Aydın Ayvalık ve Havalisi Yunan İşgali Hakkında Makamat-ı Askeriyeden Mevrud Raporlar, İkinci Kitap, Matbaa-i Askeriye, Dersaadet, 1335 .

Karayaman, Mehmet, “İzmir Valisi İzzet Bey’in Kaleminden İzmir'in İşgali”, Çağdaş Türkiye Tarihi Araştırmaları Dergisi, VI/15, Güz /2007.

Llewellyn, Michael Smith, Anadolu Üzerindeki Göz, Hürriyet Yayınları, İstanbul, Şubat 1978.

Milton, Giles, Kayıp Cennet Smyrna 1922 Hoşgörü Kentinin Yıkılışı, Şenocak Yayınları, İzmir, 2009.

Onay, Ahmet Talat, Millî Mücadele Yazıları, Haz. Cemal Kurnaz-Şefika Kurnaz, MEB Yayınları, 2. Bask1, İstanbul, 2004.

Öztoprak, İzzet, İzmir Müdafaa-i Hukuk-ı Osmaniye Cemiyeti, Atatürk Araştırma Merkezi Yayınları, Ankara, 2014.

Öktem, Haydar Rüştü, Mütareke ve İşgal Anıları, Haz. Zeki Arıkan, Türk Tarih Kurumu Yayınları, Ankara,1991.

Rodas, Mihail, I Ellada Stin Mikran Asia (1918-1922), Tipografeia, Kleisouni, 1950.

Sorguç, Erdoğan, "İlk Kurşun"un Seyir Defteri 1918-2014, Dörtyol Belediyesi Kültür Yayınları, 3. Bask1, Eylül 2016. 
Turan, Mustafa, "İstiklal Harbinde 'Müttefikler Arası Tahkik Heyeti' Çalışmaları, Raporu ve Tahkikat Neticesi”, Ankara Üniversitesi Türk İnkılap Tarihi Enstitüsü Atatürk Yolu Dergisi, S 8, 1991.

Ural, Selçuk, Okur, Mehmet, "Vali İzzet Bey'in Kaleminden İzmir'in İşgali”, A.Ü. Türkiyat Araştırmaları Enstitüsü Dergisi, S 17, Erzurum, 2001.

Yellice, Gürhan, "Megali İdea M1 Mare Nostrum Mu? Mondros Mütarekesi'nden İzmir'in İşgaline İtalyan-Yunan İlişkileri ve Propaganda Savaşı, 1918-1919”, Tarih Okulu Dergisi, S XXXVI, Ekim 2018. 